\title{
Taxon-specific variability of leaf traits in three long-ranging fossil-species of the Paleogene and Neogene: Responses to climate?
}

\author{
Anita Roth-Nebelsick, Michaela Grein, Christopher Traiser, Lutz Kunzmann, \\ Jiří Kvaček, Janina Wypich, and Johanna Kovar-Eder
}

\begin{abstract}
Data of climate-sensitive leaf traits, which are usually collected and analyzed for entire fossil leaf assemblages, also include intraspecific responses to environmental conditions. Intraspecific correlations between climate and leaf traits represent plastic responses on the individual level as well as plasticity caused by genetic differences between disjunct populations of a species. Plasticity is taxon-specific, as documented by various studies on extant plants. Data on plasticity in fossil plants are, however, rare. In this study, the plasticity of climate-sensitive leaf traits of three long-ranging species, each covering an extended time interval from the late middle Eocene to the late Oligocene or to even the early Miocene, were tracked by using material from 16 sites located in Austria, Czech Republic and Germany. Selected taxa are Daphnogene cinnamomifolia, Eotrigonobalanus furcinervis and Platanus neptuni. Leaf size-related data (lamina size, length, width) as well as leaf shape-related data (centroid, length-to-width ratio and two parameters for "roundness") were considered. All three considered fossilspecies show various site-specific and significant differences for leaf size-related traits as well as for leaf shape-related traits. Data from allochthonous marine deposits show the highest plasticity, probably due to the accumulation of heterogeneous plant material from different growing sites. For the Oligocene and Miocene, the results are mostly consistent with palaeo-temperature data. This is particularly the case for "roundness" data, confirming the suitability of this trait as an indicator for climate. The high variability of various traits found for the Eocene is, however, difficult to attribute to temperature alone. Rather, the considerable variability of Eocene trait data may be explained by environmental instability during climate transition, such as changing precipitation patterns.
\end{abstract}

Roth-Nebelsick, Anita, Grein, Michaela, Traiser, Christopher, Kunzmann, Lutz, Kvaček, Jiří, Wypich, Janina, and Kovar-Eder, Johanna. 2021. Taxon-specific variability of leaf traits in three long-ranging fossil-species of the Paleogene and Neogene: Responses to climate. Palaeontologia Electronica, 24(1):a04. https://doi.org/10.26879/1114

palaeo-electronica.org/content/2021/3285-taxon-specific-variability

Copyright: January 2021 Paleontological Society.

This is an open access article distributed under the terms of Attribution-NonCommercial-ShareAlike 4.0 International (CC BY-NC-SA 4.0 ), which permits users to copy and redistribute the material in any medium or format, provided it is not used for commercial purposes and the original author and source are credited, with indications if any changes are made. creativecommons.org/licenses/by-nc-sa/4.0/ 
Anita Roth-Nebelsick. State Museum of Natural History, Rosenstein 1, 70191 Stuttgart, Germany. anita.rothnebelsick@smns-bw.de

Michaela Grein. Übersee-Museum Bremen, Bahnhofsplatz 13, 28195 Bremen, Germany.

m.grein@uebersee-museum.de

Christopher Traiser. Department of Geoscience, University of Tübingen, Schnarrenbergstr. 94-96, 72076

Tübingen, Germany. christopher.traiser@uni-tuebingen.de

Lutz Kunzmann. Senckenberg Natural History Collections Dresden, Königsbrücker Landstr. 159, 01109

Dresden, Germany. lutz.kunzmann@senckenberg.de

Jiří Kvaček. National Museum Prague, Václavské náměsti 68, 11579 Prague 1, Czech Republic.

jiri.kvacek@nm.cz

Janina Wypich. State Museum of Natural History, Rosenstein 1, 70191 Stuttgart, Germany;

Janina.wypich@smns-bw.de

Johanna Kovar-Eder. State Museum of Natural History, Rosenstein 1, 70191 Stuttgart, Germany.

johanna.eder@smns-bw.de

Keywords: plasticity; leaves; leaf traits; palaeoclimate; Central Europe

Submission: 24 July 2020. Acceptance: 14 January 2021.

\section{INTRODUCTION}

Leaf traits are an important source of palaeoclimate information. A classic and popular leaf traitclimate relationship is the positive correlation between mean annual temperature (MAT) and the frequency of species with toothed margins, which is utilized as a proxy approach known as Leaf Margin Analysis (LMA) (Wilf, 1997; Su et al., 2010). Another approach based on a single leaf trait is the use of fossil leaf size as an indicator for humidity (Wilf et al., 1998; Jacobs and Herendeen, 2004). This is based on the observation that leaf size and precipitation tend to be positively correlated (Givnish, 1984). A widely used multivariate tool, CLAMP, utilizes the correlations between leaf traits and climate parameters (Wolfe, 1995; Spicer et al., 2009; Yang et al., 2015). Recently, some new traitclimate correlations were described. The number and area of leaf teeth was shown to be negatively correlated with MAT, which is part of a quite general response of leaf circularity to climate (Huff et al., 2003; Peppe et al., 2011; McKee et al., 2019). Circularity describes the degree of "roundness", ranging from 1 (a perfect circle) to 0 (a line), and declines with the degree of leaf dissection, with the latter decreasing significantly with MAT (Peppe et al., 2011).

Data for climate-sensitive leaf traits are usually collected and analyzed for entire leaf assemblages of the local vegetation. The total leaf trait data of a specific site consist not only of the sitespecific taxonomic composition, but also of phenotypic variability within the studied taxa. This intraspecific phenotypic variability is caused by plas- ticity, the ability of organisms to change their phenotype according to environmental conditions. In fact, plasticity is acknowledged as an important factor for the trait-climate relationships revealed by CLAMP data sets (Yang et al., 2015). Royer (2008) and McKee (2019) found for various species that 1) leaves tend to become more dissected when the plants are growing in colder climate, 2) leaf area responds negatively to temperature, while 3 ) circularity increases with increasing temperature. Intraspecific plasticity can also be caused by genetic differences between disjunct populations of a species, termed ecotypes, representing in many cases adaptations to regional climate (Larcher, 2003). To identify genetic differences between populations, "common garden experiments" are conducted, meaning the cultivation of individuals from different locations at one site. It is then tested whether population-specific trait differences are expressed at the cultivation site, which is taken as evidence of genetical differences between populations (Hufford and Mazer, 2003).

For various leaf traits, plasticity, ecotype evolution and interspecific evolutionary trends appear follow similar directions, as suggested by various data. For example, studies conducted by McKee et al. (2019) and Royer $(2008,2009)$ showed that plastic responses of leaf dissection and leaf circularity to temperature were largely consistent with the global correlations found by Peppe et al. (2011). Another example is provided by temperate heteroblastic species of Viburnum, in which the sequence of stronger dissected leaves emerging during spring are followed by less dissected sum- 
mer leaves. This parallels the evolution of leaf types in different climate zones (Spriggs et al., 2018). Data provided by McKee et al. (2019) for four deciduous woody species (Quercus rubra L., Acer negundo, Carpinus caroliniana and Ostrya virginiana (Mill.) K.Koch) indicate that leaf size responses to temperature are taxon-specific. Plasticity itself is controlled and regulated by genes (Chitwood and Sinha, 2016) and interspecific differences among species are therefore probable. For example, in the case of Quercus kelloggii, no response of leaf traits to temperature could be detected (Royer et al., 2008).

Generally, correlations between climate and leaf traits are considered to be the result of convergent evolution with the leaf traits representing adaptations to environmental conditions. Often, however, the concrete benefits of a single trait have not yet been clarified. For instance, the positive correlation between leaf size and humidity could be explained by water relations, because large leaves require sufficient water availability and small leaves should therefore be advantageous in drier habitats. In fact, however, leaf size is also affected by other environmental parameters, such as temperature (Dolph and Dilcher, 1980) or light (Scoffoni et al., 2015). On a global scale, leaf size tends to be positively correlated with both temperature and humidity (Wright et al., 2017). The responses of leaf traits to environmental conditions are complex, because individual characters may have more than one function, and many climate parameters are correlated with one another. In fact, it has been shown that leaf traits are often intercorrelated (Yang et al., 2015).

Although intraspecific variability is to be expected to be present in fossil plants, detailed information on intraspecific variability are sparse. Taxon-specific changes in the leaf traits of Rhodomyrtophyllum reticulosum from the middle to late Eocene and Platanus neptuni from the late middle Eocene to early Miocene were reported and discussed recently by Moraweck et al. (2019), considering leaf size and also various micromorphological traits found for leaf cuticles. Besides showing distinct site-specific variances, the results also indicated a possible influence of depositional setting caused by habitat conditions (Moraweck et al., 2019). For various taxa from two Oligocene sites of the Paleogene Basin of Hungary, which show similar age and taxonomic composition, intraspecific differences in leaf size and ratio of leaf length to width could be demonstrated (Tamás and Hably, 2009). For the fossil species Eotrigonobala- nus furcinervis, which is one of the three study taxa herein, evidence for a significant increase in leaf area between two Eocene sites of almost identical environmental settings was found by Toumoulin et al. (2020).

More information on palaeo-variability is needed because trait-climate correlations are the result of responses on three different levels: 1) habitat preferences of taxa bearing climate-sensitive traits, 2) intraspecific plasticity (ecotypes) and 3) sub-individual phenotypic plasticity. In this study, climate-sensitive leaf traits of three long-ranging species, each covering an extended time interval from the late middle Eocene to the late Oligocene or to even the early Miocene, were tracked. Besides leaf size-related data, such as lamina perimeter, also leaf shape-related data, such as circularity data, were collected. Selected fossilspecies are Daphnogene cinnamomifolia, Eotrigonobalanus furcinervis and Platanus neptuni. Note that the aims of the present study do not include a contribution to trait-climate correlations, which are utilized in leaf-based tools for reconstructing palaeoclimate, such as Yang et al. (2015). Rather, the aim of this study was to investigate plasticity of fossil-species, by addressing the following questions: 1) What is the degree of plasticity in the considered fossil-species, as compared to extant plasticity data? 2) What is the "plasticity behavior" over time (is there a possible evolutionary change)? 3) Are there significant site-specific differences in leaf traits exhibited by the three taxa? 4) Are these differences consistent with palaeoclimate, palaeogeography and stratigraphic trends? 5) Are there any effects detectable which are due to depositional settings?

\section{TAXA, SITES AND METHODS}

\section{Taxa}

Platanus neptuni (Ettingsh.) Bůžek, Holý \& Kvaček (Platanaceae) occurred under warm-temperate to 'subtropical' climates from the late middle Eocene to the early Miocene in central Europe. For NW Romania, fossil material exists for $P$. neptuni dating back to the late Miocene (Kvaček and Manchester, 2004). It was also recovered from the Oligocene of Oregon (Manchester and Kvaček, 2010). P. neptuni was a thermophilous tree species, originally described as deciduous (Kvaček and Manchester, 2004), quite tolerant with respect to environment, and was able to grow in different habitats (Walther, 1985). P. neptuni thrived in zonal communities and riparian forests, in both mixed 
mesophytic forests and evergreen broadleaved forests. For the present study, data for $P$. neptuni considered by Moraweck et al. (2019) were used, together with additionally collected data.

Eotrigonobalanus furcinervis (Rossm.) Walther \& Kvaček (Fagaceae) occurred in Europe and western Asia from the middle Eocene to the uppermost Oligocene. Other occurrences of leaves have been reported from the Danian of western Greenland (Grímsson et al., 2016) and from the Oligocene of Greece (Velitzelos et al., 2014). Based on its rich occurrences at many Eocene to Oligocene sites, the supposedly evergreen E. furcinervis represented a quite common element both of riparian and swamp forests (azonal settings) and of the zonal evergreen broadleaved vegetation in the Eocene. Later, in the early Oligocene, it probably represented more of an accessory element of the zonal mixed mesophytic forests but still preferred azonal settings such as swamp and riparian forests. In the late Oligocene, the preferred habitats of E. furcinervis were either swamp environments (Kvaček and Walther, 1989; Mai and Walter, 1991) or lacustrine settings (Walther, 1999). Mai and Walther (1985) and Mai (1995) concluded that evergreen Fagaceae including $E$. furcinervis were common in late Eocene zonal lowland FagaceaeLauraceae forests. Its occurrence appears to be quite independent of facies settings, suggesting a wider range of habitats suitable for $E$. furcinervis (Kriegel, 2001).

Daphnogene cinnamomifolia (Brongn.) Unger (Lauraceae) represents another frequent fossilspecies with a wide stratigraphic range, recorded from the Paleogene and Neogene vegetation (Kvaček and Walther, 1998). D. cinnamomifolia was evergreen, with coriaceous leaves and preferred zonal communities. With respect to taxonomy, D. cinnamomifolia represents a special case, compared to Eotrigonobalanus furcinervis and Platanus neptuni. Although taxonomic identification of fossil leaves is often challenging, this is particularly the case for Lauraceae leaves, and D. cinnamomifolia may represent a morphotype which in fact encompasses more than one species (Kvaček and Knobloch, 1967). It was shown that leaf morphometric traits of the extant genus Cinnamomum, which includes many species similar in leaf morphology to $D$. cinnamomifolia, are climate-sensitive and little constrained by phylogeny (Tanrattana et al., 2020). Therefore, D. cinnamomifolia was considered in this study with the caveat that leaf trait variability may also include some interspecific variability. As will be shown, leaves of $D$. cinnamomifo- lia occupy a quite clearly delimited realm in the leaf morphospace.

All leaf specimens are included in the database Morphyll (http://www.morphyll.naturkundemuseum-bw.de/index.php), which is publicly accessible and described in Traiser et al. (2018). The data set used for this study can be found in Appendix 1.

\section{Sites}

Material from 16 fossil sites in central Europe was considered in the study (Table 1, Figure 1), including locations from the Leipzig Embayment and Kleinsaubernitz [described in detail by Moraweck et al. (2019)], Rauenberg (hitherto all situated in Germany), as well as sites from the Bohemian Massif [summarized in Teodoridis and Kvaček (2015)] (please note that the ages of the various sites were determined by different methods, see Table 1; age values which were not obtained radiometrically are approximate). Additionally, the sites Linz and Eferding, Austria, were included. The material belongs to various collections housed in four institutions (Senckenberg Natural History Collections Dresden, National Museum Prague, State Museum of Natural History Stuttgart and Naturhistorisches Museum Wien) (Table 1).

Rauenberg, close to the city of Wiesloch (Germany), is located in the upper Rhine Valley and the Mainz Basin. The Rauenberg site is a former clay pit harboring fossil-rich marine sediments of Rupelian age [described by Maxwell et al. (2016) and Kovar-Eder (2016)]. The fossil-bearing sediments of Kleinsaubernitz are quite close to fossil coastal lowlands like the Leipzig Embayment. They are, however, lacustrine and represent maar sediments containing a quite rich "volcanic" fossil flora from the late Oligocene (Walther, 1999). Various sites close to the city of Linz and Eferding (both Austria) are located in the North Alpine Foreland Basin and contain marine sediments from the Central Paratethys of the lower Miocene (Grunert et al., 2010; Grunert et al., 2015). The fossil floras were described by Kovar-Eder and Berger (1985) and Kovar (1982).

The ages of the sites range from the late middle Eocene to the lower Miocene and therefore cover a number of major global climate transitions recorded by marine data, including the late Eocene cooling with the distinct cooling event at the Eocene-Oligocene Transition (EOT; Hutchinson et al., 2020), a warming trend in the late Oligocene and the Oligocene-Miocene boundary (Pälike et al., 2006; Zachos et al., 2008; Eldrett et al., 2009; 
TABLE 1. Summary of the considered sites. Collections: aSenckenberg Natural History Collections Dresden, bNational Museum Prague, cState Museum of Natural History Stuttgart, dNaturhistorisches Museum Wien. *Absolute ages are if not radiometrically determined - estimated from information available for the stratigraphic position of the sites. Abbreviations for dating: RM: radiometric. BS: biostratigraphy. LS: lithostratigraphy. The literature sources for dating and further information on the sites are indicated with superscript letters: ${ }^{1} \mathrm{Krutzsch}$ (2011), ${ }^{2}$ Bellon et al. (1998), ${ }^{3} \mathrm{Knobloch}$ et al. (1996), ${ }^{4}$ Rojík (2004), ${ }^{5}$ Moraweck et al. (2019), ${ }^{6}$ Standke et al. (2010), ${ }^{7} \mathrm{Krutzsch}$ et al. (1992), ${ }^{8} \mathrm{Grimm}$ et al. (2002), ${ }^{9}$ Standke (2008), ${ }^{10} \mathrm{Cajz}$ (2000), ${ }^{11} \mathrm{Cajz}$ (1999), ${ }^{12 K v a c ̌ e k ~ a n d ~ W a l t h e r ~(2003), ~}{ }^{13}$ Teodoridis, and Kvaček (2015), ${ }^{14}$ Pers. comm. Miroslav Radon, Regional Museum of Teplice, Czech Republic, ${ }^{15} \mathrm{Goth}$ et al. (2003), ${ }^{16}$ Rupp and Ćorić (2012b), ${ }^{17}$ Grunert et al. (2015), ${ }^{17}$ Rupp and Ćorić (2012a). Abbreviations for depositional setting: F: fluviatile. M: marine. V: volcanic. Abbreviations for Taxa: EF: Eotrigonobalanus furcinervis. DC: Daphnogene cinnamomifolia. PN: Platanus neptuni. Numbers in brackets indicate the number of available leaves. MAT and StD: Mean annual temperature and standard deviation, determined by CLAMP. GSP and StD: Growing season precipitation and standard deviation, determined by CLAMP. CLAMP results from Moraweck et al. (2019), with the exception of sites marked with an asterisk, which were taken from Teodoridis and Kvaček (2015). N.a.: data not available.

\begin{tabular}{|c|c|c|c|c|c|c|}
\hline Site & Site ID & Age* $^{*}$ & $\begin{array}{l}\text { Depositional } \\
\text { setting }\end{array}$ & $\begin{array}{c}\text { Leaf } \\
\text { material }\end{array}$ & $\begin{array}{l}\text { MAT } \pm \\
\text { StD }\end{array}$ & $\mathrm{GSP} \pm \mathrm{StD}$ \\
\hline $\begin{array}{l}\text { Profen-Schwerzau } \\
1 u^{a}\end{array}$ & 1 & $\begin{array}{c}\text { Bartonian }^{1} \\
40-37.8 \text { (BS) }\end{array}$ & $\mathrm{F}$ & $\mathrm{PN}(7)$ & $18.0 \pm 2.1$ & $2106.3 \pm 317$ \\
\hline Kučlínb & 2 & $\begin{array}{c}\text { Priabonian }^{2} \\
38.3 \pm 0.9 \mathrm{Ma}(\mathrm{RM})\end{array}$ & V & $\begin{array}{l}\text { DC (21) } \\
\text { PN (21) }\end{array}$ & $16.8 \pm 1.3^{*}$ & $1267 \pm 497$ \\
\hline Klausaa & 3 & $\begin{array}{c}\text { Priabonian }{ }^{1} \\
37.8-34.8(B S)\end{array}$ & $\mathrm{F}$ & $\mathrm{DC}(17)$ & $18.6 \pm 1.3$ & $700 \pm 497$ \\
\hline $\begin{array}{l}\text { Svatava - Na } \\
\text { Pískách }{ }^{b}\end{array}$ & 4 & $\begin{array}{c}\text { Priabonian }{ }^{3,4} \\
37.8-34 \text { Ma (BS }- \text { Stare Sedlo } \\
\text { Formation) }\end{array}$ & $\mathrm{F}$ & $\mathrm{DC}(6)$ & n.a. & n.a. \\
\hline Český Chloumek & 5 & $\begin{array}{c}\text { Priabonian } 3,4 \\
37.8-34 \text { Ma (BS - Stare Sedlo } \\
\text { Formation) }\end{array}$ & $\mathrm{F}$ & $\begin{array}{l}\mathrm{DC}(10) \\
\mathrm{EF}(20)\end{array}$ & n.a. & n.a. \\
\hline Schleenhain-2o-3ua & 6 & $\begin{array}{c}\text { Priabonian } 1,5,6 \\
36.4-34.8 \text { (LS, BS) }\end{array}$ & $\mathrm{F}$ & EF (18) & $19.4 \pm 2.1$ & $2200.7 \pm 317$ \\
\hline Schleenhain-HCa & 7 & $\begin{array}{c}\text { Rupelian } 1,5,6 \\
33.9-33.0 \text { (LS, BS) }\end{array}$ & $\mathrm{F}$ & $\mathrm{PN}(12)$ & $14.2 \pm 1.3$ & $654.5 \pm 497$ \\
\hline Haselbach-HCa & 8 & $\begin{array}{c}\text { Rupelian } 1,5,6,7 \\
33.9-32 \text { (LS, BS) }\end{array}$ & $\mathrm{F}$ & $\mathrm{EF}(7)$ & $11.6 \pm 1.3$ & n.a. \\
\hline Rauenbergc & 9 & $\begin{array}{c}\text { Rupelian }^{8} \\
32.4-30.5 \text { (BS) }\end{array}$ & $\mathrm{M}$ & $\begin{array}{l}\text { DC (48) } \\
\text { PN (41) }\end{array}$ & $18.0 \pm 1.3$ & $1323.0 \pm 497$ \\
\hline Seifhennersdorfa & 10 & $\begin{array}{c}\text { Rupelian², } \\
30.7 \pm 0.7 \mathrm{Ma}(\mathrm{RM})\end{array}$ & V & $\mathrm{PN}(7)$ & $10.0 \pm 1.3$ & $849.4 \pm 497$ \\
\hline $\begin{array}{l}\text { Markvartice u } \\
\text { Děčínab }\end{array}$ & 11 & $\begin{array}{c}\text { Rupelian 10, 11, 12, 13, } 14 \\
30 \text { - } 28 \text { (BS, LS, pers. comm.) }\end{array}$ & V & PN (32) & $11.9 \pm 1.3^{*}$ & $1425.7 \pm 497$ \\
\hline Kleinsaubernitza & 12 & $\begin{array}{c}\text { Chattian } 1,15 \\
27.5-26.5 \text { (BS) }\end{array}$ & V & EF (18) & $13.4 \pm 1.3$ & $850.4 \pm 497$ \\
\hline $\begin{array}{l}\text { Borna-Ost/ } \\
\text { Bockwitz-TC } \\
(\mathrm{BOB})^{\mathrm{a}}\end{array}$ & 13 & $\begin{array}{c}\text { Chattian }^{1} \\
25.5-24.5(\mathrm{BS})\end{array}$ & $\mathrm{F}$ & $\mathrm{PN}(25)$ & $10.1 \pm 1.3$ & $878.4+497$ \\
\hline Witznitz-WCa & 14 & $\begin{array}{c}\text { Chattian }^{1} \\
24.5-23 \text { (BS) }\end{array}$ & $\mathrm{F}$ & $\begin{array}{l}\text { EF (14) } \\
\text { PN (17) }\end{array}$ & $13.8 \pm 1.3$ & $791.4+497$ \\
\hline Eferdingd & 15 & $\begin{array}{l}\text { Chattian-Aquitanian }{ }^{16,}, 17 \\
27-23 \mathrm{Ma}(\mathrm{BS})\end{array}$ & M & $\mathrm{DC}(11)$ & n.a. & n.a. \\
\hline $\operatorname{Linz}^{d}$ & 16 & $\begin{array}{l}\text { Aquitanian } 17,18 \\
23-22 \text { (BS) }\end{array}$ & $\mathrm{M}$ & PN (16) & $16.0 \pm 1.3$ & $1147.5 \pm 497$ \\
\hline
\end{tabular}




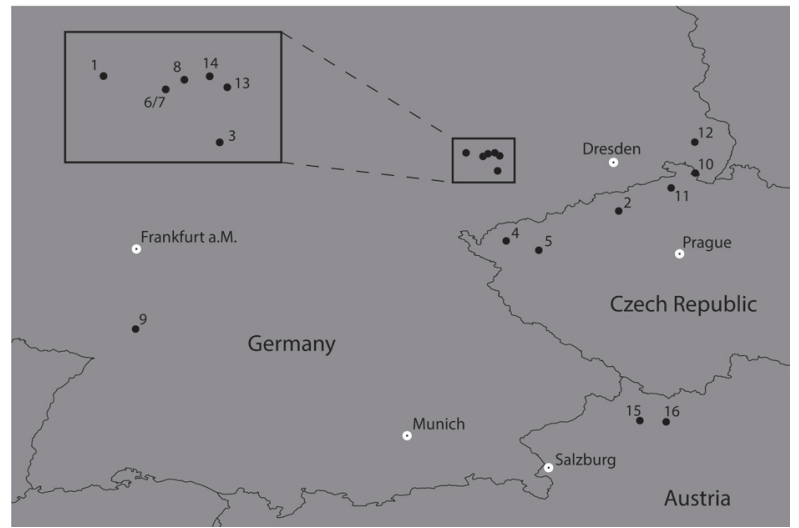

FIGURE 1. Map showing the locations of the considered sites, which are numbered according to Table 1 .

Hren et al., 2013). The depositional settings of the considered sites are different and include fluvial, lacustrine ("volcanic") and marine sediments. The lacustrine sediments originate mostly from maar lakes or other lakes, shaped by tectonic and/or volcanic activity, and will be termed "volcanic" throughout the rest of the text (Akhmetiev et al., 2009). All sites and information with respect to dating and depositional setting are summarized in Table 1. To evaluate the results with respect to palaeoclimate, climate data available for the sites were compiled. These comprise various data based on CLAMP and on the Coexistence approach for the considered area (Moraweck et al., 2015, 2019; Teodoridis and Kvaček, 2015; Kunzmann et al., 2016).

\section{Selected Leaf Traits}

For the fossil leaves, the following parameters were considered: 1) leaf size-related traits: lamina area, perimeter, length, width and 2) leaf shaperelated traits: lamina circularity, lamina roundness and lamina centroid. In the present study, effective leaf width was determined by QGIS (see below), based on the "bounding box". The bounding box is a rectangle in which the leaf fits completely, i.e., without any part of the lamina crossing the sides.

Lamina circularity and roundness can be derived as follows. Lamina circularity (LC), also termed shape factor, is defined by $\left(A_{\text {lamina }}=\right.$ leaf lamina area, and $P=$ leaf perimeter):

$$
L C=4 \pi \cdot \frac{A_{\text {lamina }}}{P^{2}}
$$

Another parameter describing the similarity of the lamina shape with a circle is lamina roundness (LR) (with $D_{\text {cal }}=$ maximum caliper diameter):

$$
L R=\frac{4}{\pi} \cdot \frac{A_{\text {lamina }}}{\left(D_{\text {cal }}\right)^{2}}
$$

$D_{\text {cal }}$ is calculated as the longest distance between any two points on the lamina outline. The advantage of lamina roundness is that it is less dependent on lamina perimeter, which often rises substantially when small but densely packed leaf teeth are present. Both LC and LR can adopt values between 0 and 1 . The smaller the value, the larger is the difference to a circle, and 1 corresponds to a perfect circle.

Lamina centroid (LCE) means the distance (D) of the area-based centre of gravity from the lamina base, expressed relative to leaf length $(L)$, in percent:

$$
L C E=\frac{D \cdot 100}{L}
$$

The LCE indicates the "ovateness" of a leaf: ovate leaves show a low value while obovate leaves show a high value. For example, a value of $50 \%$ corresponds to a centre of gravity exactly in the middle length of lamina whereas a value of $60 \%$ indicates a more obovate shape due to an apical shift of the centre of gravity.

Additionally, the length-to-width ratio (LWR) was included.

$$
\text { LWR = lamina length/lamina width }
$$

\section{Image Acquisition and Digitalisation}

The fossil leaves were photographed by using a copy stand and a Nikon 5100, or a Canon EOS 6D camera with a Canon 100 macro lens or scanned using a Canon CanoScan 5600F showing a high depth of field. The digital images were then rotated in order to align the main parts of the primary (central) leaf vein vertically by using Adobe Photoshop 10.0, 11.0 and CS5.1 (http:// adobe.com). Finally, the images were size calibrated using ImageJ 1.46a (http://rsb.info.nih.gov/ $\mathrm{ij} /$ ). The leaf outlines visible in the images were digitized with QGIS 2.0 - 2.8 (http://qgis.org), an open source geographic information system (GIS). For this purpose, the images of fossil leaves were georeferenced to the uppermost part of the leaf petiole (if preserved in the fossil) which represents the "origin" of all leaf images. The resulting GIS shapefiles 
of lamina outlines were used to calculate leaf morphometric parameters by spatial SQL-queries. For this purpose, the shapefiles were imported into an object-relational PostgreSQL 9.1.19 database (http://www.postgresql.org) with PostGIS 2.0.4 (http://postgis.org) extension, which adds support for spatial queries to be run in SQL. Further details are described and discussed in Roth-Nebelsick et al. (2017) and Traiser et al. (2018).

Fossil leaves are often fragmented. Therefore, incompletely preserved leaves were included in the study when reconstruction of the total lamina outline was possible from the preserved leaf area, on the basis of the morphology of the considered species. This was quite feasible in many cases for Daphnogene cinnamomifolia and also Platanus neptuni, and much more difficult in Eotrigonobalanus furcinervis, due to differences in taxon-typical size and shape (see Toumoulin et al., 2020). For detailed explanation and discussion of the applied procedures see Traiser et al. (2018) and Moraweck et al. (2019). The number of suitable leaves per site is provided in Table 1.

\section{Plasticity Index}

The plasticity index $\mathrm{PI}$, introduced by Valladares et al. (2000), is a measure of the degree of variability. It is calculated from measured trait data as $\mathrm{PI}=[($ maximum value - minimum value $) /$ maximum value] $\times 100$.

\section{Leaf Mass per Area}

$\mathrm{LM}_{\text {area}}$, meaning the ratio between leaf dry weight and lamina area, is an important parameter in leaf economics (Wright et al., 2004). Due to its significant correlation with leaf longevity, it can be utilized to estimate leaf life span of fossil plants (Royer et al., 2007; Harris and Arens, 2016; Lowe et al., 2018). On the basis of petiole width (PW) and lamina area, leaf mass per area ( $\left.\mathrm{LM}_{\text {area }}\right)$ can be determined approximately, according to Royer et al. (2007):

$$
\log \left(\mathrm{LM}_{\text {area }}\right)=a+b^{*} \log \left(P W 2 / A_{\text {lamina }}\right)
$$

with $a$ and $b$ as constants $(a=3.070, b=0.382)$ (Royer et al., 2007).

\section{Statistics}

For the three taxa, statistical significance of differences in the considered leaf traits was evaluated between sites within age groups. The considered age groups comprise age intervals: late Eocene, early Oligocene, late Oligocene and early
Miocene. All statistical procedures were conducted by using SYSTAT 13.1, Systat Software, Inc.

Statistical significance was determined by ANOVA (for more than two groups) or with the ttest (in the case of two groups). Both tests require a normal distribution and equal variances. Normal distribution and equality of variances were tested with the Shapiro-Wilk test and the Levene test for homogeneity. Raw data sets, which did not show a normal distribution were $\log _{10}$-transformed or - if necessary - the Box-Cox transformation was applied (Sokal and Rohlf, 2012). Often, homoscedasticity was markedly improved by data transformation. As PostHoc Test, the Bonferroni test was applied in the case of normal distribution and equal variances. In the case of non-equal variances, the Games-Howell test was selected. In rare cases, a normal distribution could not be achieved, and a distribution-free test, the Kruskal-Wallis test, was then used, with a PostHoc test (Dwass-SteelChritchlow-Fligner). For all tests, significance level was at least $\alpha=0.05$.

To evaluate the morphospace of the different taxa with respect to all considered leaf traits, a classical discriminant analysis was conducted for the Eocene and Oligocene. For the Miocene, not enough data were available to conduct a meaningful discriminant analysis.

\section{RESULTS}

\section{Leaf Mass per Area}

The material allowed for the approximate calculation of $\mathrm{LM}_{\text {area }}$, with 64 suitable leaves for Platanus neptuni and 56 leaves for Daphnogene cinnamomifolia. Based on the equations provided by Royer et al. (2007), $\mathrm{LM}_{\text {area }}=95.5 \mathrm{~g} / \mathrm{m}^{2} \pm 25.1$ for $P$. neptuni and for $D$. cinnamomifolia $\mathrm{LM}_{\text {area }}=$ $104.7 \mathrm{~g} / \mathrm{m}^{2} \pm 29.6$. For Eotrigonobalanus furcinervis, only six leaves were available for determining $L_{\text {area }}$. Here, the result was distinctly lower, amounting to $64.3 \mathrm{~g} / \mathrm{m}^{2} \pm 14.4$. All results are significantly different from each other.

Whereas the data confirm the general assumption of Daphnogene cinnamomifolia representing an evergreen taxon, the result for Platanus neptuni is close to the boundary between deciduousness and evergreenness $\left(87 \mathrm{~g} / \mathrm{m}^{2}\right)$ as suggested by Royer et al. (2007). A deciduous leaf habit was concluded by Kvaček and Manchester (2004) for P. neptuni, based on the position of leaf buds, which are covered by the petioles of the mature leaves. Development of new leaves would 
therefore require the shedding of the older leaves. Furthermore, Kvaček and Manchester (2004) argue that mass occurrences of leaves of $P$. neptuni would further support deciduousness.

The terms "evergreen" and "deciduous" originally apply to the whole plant, meaning whether the canopy is green throughout the year or leafless during a certain time interval (Kikuzawa and Lechowicz, 2011). Within this context, the term "semi-evergreen" (sometimes also called "semideciduous" and "brevideciduous") describes a situation in which the abscission of old leaves and emergence of new leaves follow immediately one after the other. The plant is therefore continuously green while the leaf longevity is often about one year. From the "leaf perspective", a leaf longevity of 12 months is usually considered "evergreen" (Givnish, 2002). As already pointed out by Moraweck et al. (2019), it is quite probable that Platanus neptuni represented such a semi-evergreen taxon, a situation which would be perfectly consistent with the conclusions of Kvaček and Manchester (2004). Additionally, reconstructions of palaeoclimate for fossil sites, which contain material of $P$. neptuni often indicate a rather long growing season (Moraweck et al., 2019), supporting the notion of a semi-evergreen habit.

Evergreenness of Eotrigonobalanus furcinervis was concluded by several authors (e.g., Kvaček and Walther, 1989) based on the supposed botanical affiliation of the genus within the trigonobalanoid clade of Fagaceae, which consists of evergreen extant species only. However, Grímsson et al. (2016) place a group of extinct trigonobalanoids as a separate entity as sister to the extant clade in their phylogenetic analysis of Fagaceae. For E. furcinervis, the data do not support the interpretation of the leaves as evergreen. Rather, the results indicate deciduousness. With six leaves suitable for allowing calculation of $\mathrm{LM}_{\text {area }}$, the data set was, however, limited. The data do not provide a clear-cut answer to the question whether $E$. furcinervis was deciduous or not, and the topic requires further analysis.

In short, the data for $L_{\text {area }}$ obtained in this study support the current evidence for foliar habit in Daphnogene cinnamomifolia and Platanus neptuni. In the case of Eotrigonobalanus furcinervis, there are possibly not enough data available. It should, however, be noted that data relating leaf life span and $\mathrm{LM}_{\text {area }}$ show a considerable scatter (for example, Enrique et al., 2016), hampering a clear-cut distinction between evergreen leaves and deciduous leaves based on $L_{\text {area. }}$. Furthermore, there is a certain species-specific increase of $\mathrm{LM}_{\text {area }}$ with rising $\mathrm{CO}_{2}$ (about $20 \%$ increase on average for 800 ppm compared to the extant level, Poorter et al., 2009). However, $L M_{\text {area }}$ is also affected by various other environmental parameters, such as water availability, temperature and also irradiation (Poorter et al., 2009). Environmental effects on $\mathrm{LM}_{\text {area }}$ of fossil leaves are therefore difficult to pinpoint under changing climate conditions.

\section{Plasticity Index}

Plasticity is highest for data related to leaf size, lamina area, perimeter, length and width (Figure 2). Leaf centroid is much less plastic, while circularity and roundness show medium plasticity (Figure 2). There are, however, considerable sitespecific differences in plasticity. These are partially caused by the number of available leaves per site, because a certain amount of data is necessary to capture trait variability. As indicated by the data set, about 10 leaves can provide a reasonable approximation for plasticity within the fossil material, because from around 10 data points a relatively stable average value is established. The extremely low plasticity in the case of ProfenSchwerzau, for which only Platanus neptuni leaves were available for this study, may at least partly be caused by a low number of available leaves (Figure 2). It is, however, also possible that low PI reflects environmental conditions (see discussion section). From the entire data set (Figure 2), it seems that $\mathrm{PI}$ tends to higher values for marine deposits (Figure 2).

\section{Leaf Size-Related Traits}

Site-specific leaf size data vary particularly strongly for the Eocene for all taxa, with mostly significant differences between sites (Figures 3-4). This high variability in leaf size-related data is distinctly shown by Daphnogene cinnamomifolia, which provided the largest amount of material for the Eocene sites (Figure 3E-F and Figure 4E-F). In Eotrigonobalanus furcinervis, perimeter and length show statistically significant differences for the Priabonian sites, in contrast to lamina area and width, indicating that leaves from the Český Chloumek site are shorter than at the other sites.

Variability of leaf size during the early Oligocene and late Oligocene appears to be much lower for all taxa. Platanus neptuni shows some significant site-specific differences in leaf length and leaf width data from the early Oligocene. For the early Miocene, $P$. neptuni leaf size data indicate a substantial rise, compared to the Oligocene data, 

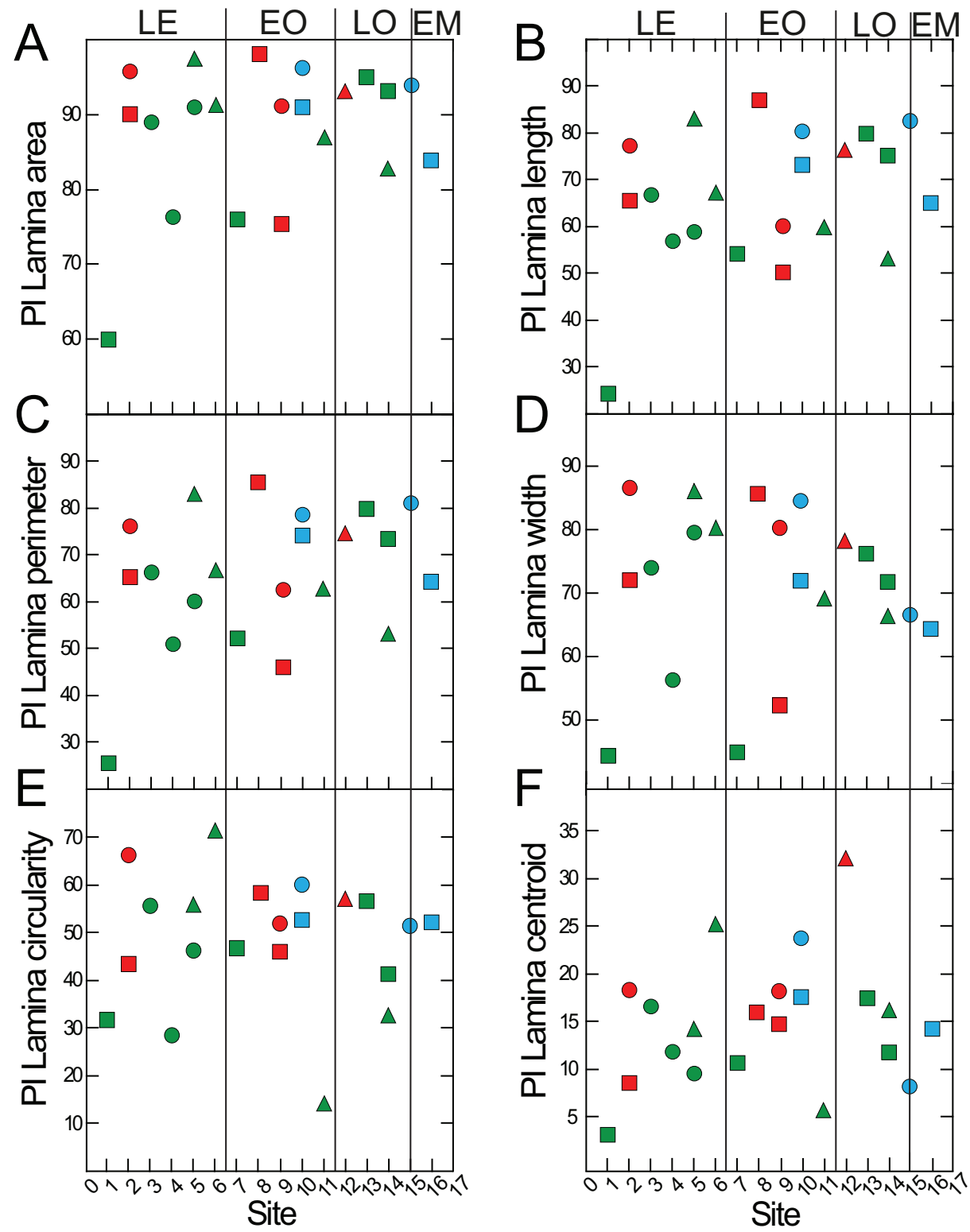

FIGURE 2. Plasticity index (PI) of various leaf traits, for the considered sites and taxa. 2A: PI for lamina area. 2B: PI for lamina length. 2C: PI for lamina perimeter. 2D: PI for lamina width. $2 \mathrm{E}$ : $\mathrm{PI}$ for lamina circularity. $2 \mathrm{~F}$ : PI for lamina centroid. Squares: Platanus neptuni. Circles: Daphnogene cinnamomifolia. Triangles: Eotrigonobalanus furcinervis. Colors indicate deposit type. Green: fluviatile. Red: volcanic. Blue: marine. Lines delimit age groups. LE: Late Eocene. EO: Early Oligocene. LO: Late Oligocene. EM: Early Miocene. For site numbers and dating see Table 1.

whereas leaf size of Daphnogene cinnamomifolia does not show considerable differences between the Eferding site (early Miocene group) and the early Oligocene data.

\section{Leaf Shape-Related Traits}

With respect to circularity and roundness (Figure 5), site-specific differences between Eocene sites are all significant for Eotrigonobalanus furcinervis and Daphnogene cinnamomifolia. Circularity and/or roundness show a trend towards lower values from the Eocene and early Oligocene to the late Oligocene for Platanus neptuni (Figure 5A-B). For the early Oligocene, there appears to be no clear trend with respect to circularity and roundness in P. neptuni (Figure 5A-B). A statistically significant difference is, however, shown between circularity values of the Chattian sites, followed by a higher value for the Aquitanian (Figure 5A). In $D$. cinnamomifolia, circularity and roundness tend to 

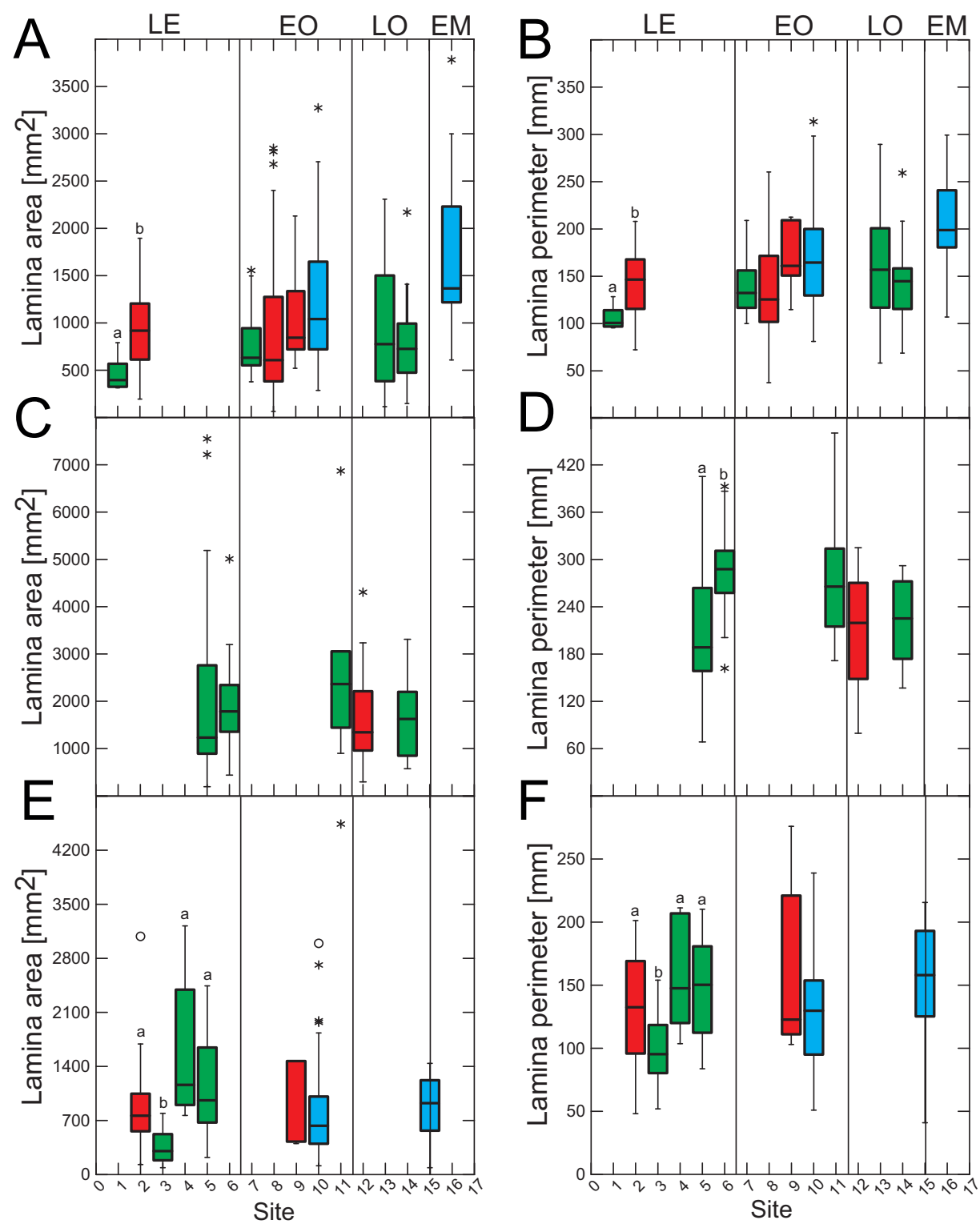

FIGURE 3. Site-specific data for lamina area and lamina perimeter plotted for each taxon. 3A: Lamina area for Platanus neptuni. 3B: Lamina perimeter for P. neptuni. 3C: Lamina area for Eotrigonobalanus furcinervis. 3D: Lamina perimeter for $E$. furcinervis. 3E: Lamina area for Daphnogene cinnamomifolia. 3F: Lamina perimeter for $D$. cinnamomifolia. The boxes span the $50 \%$ interquartile. The horizontal lines within the boxes indicate the median values. The "whiskers" mark the highest and lowest values. Outliers located at a distance of up to 1.5 times the quartile span outside the whiskers are drawn as asterisks, and extreme outliers are drawn as circles. Different minuscule letters indicate statistically significant differences among sites. Colors indicate deposit type. Green: fluviatile. Red: volcanic. Blue: marine. Lines delimit age groups. LE: Late Eocene. EO: Early Oligocene. LO: Late Oligocene. EM: Early Miocene. For site numbers and dating see Table 1.

lower values from the Eocene to the early Oligocene, although quite low Eocene values do also exist (Figure 5E-F). Also, circularity is low for the Chattian-Aquitanian in D. cinnamomifolia (Figure $5 \mathrm{E})$. For E. furcinervis, no statistically significant differences could be detected for circularity and roundness data of the Oligocene sites (Figure 5CD).

Despite low plasticity in LCE, the centroid data also show statistically significant differences for the Eocene (Figure 6A, 6C, 6E) and here also for Eotrigonobalanus furcinervis (Figure 6C). For the early Oligocene, LCE data show no significant 

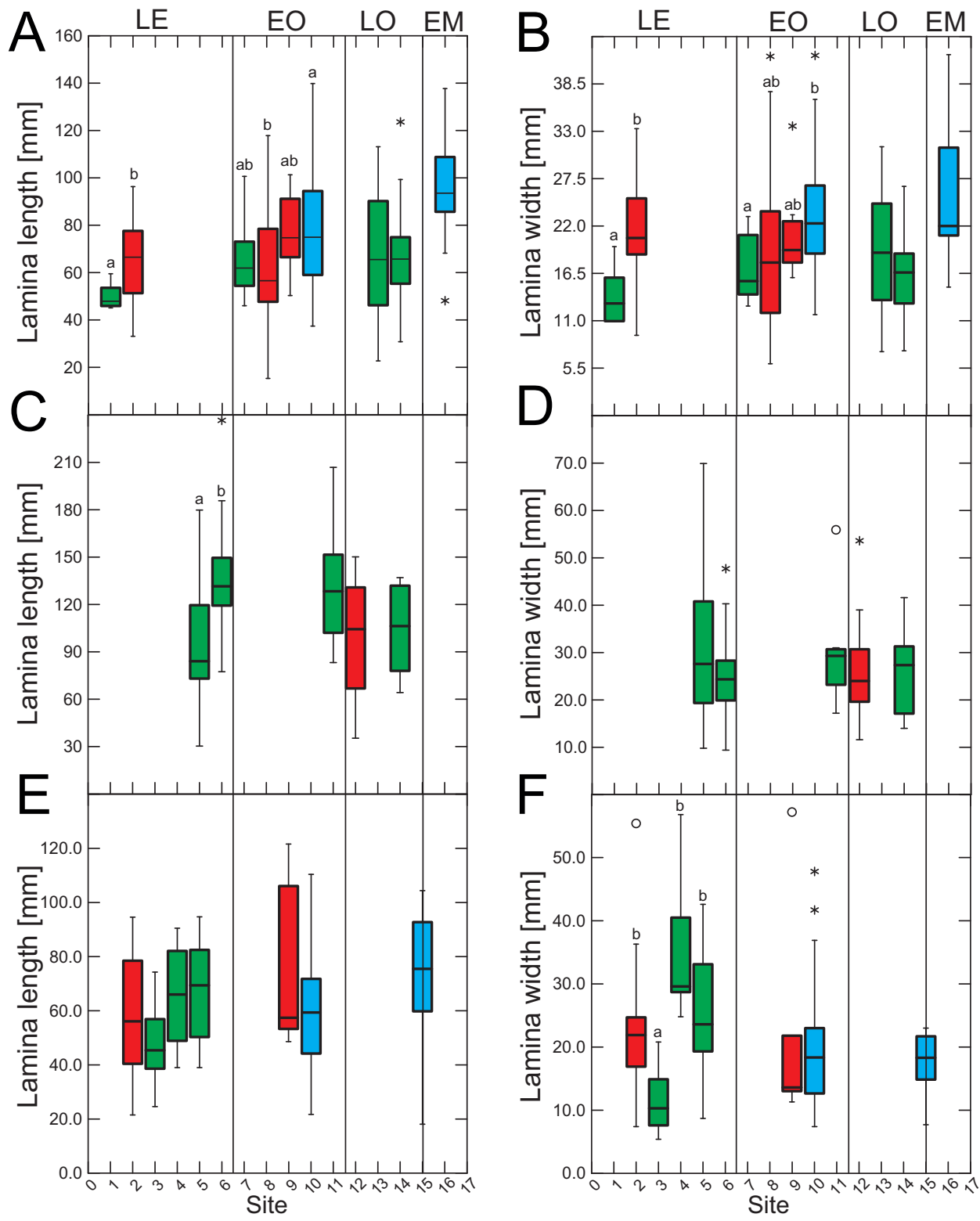

FIGURE 4. Site-specific data for lamina length and lamina width plotted for each taxon. 4A: Lamina length for Platanus neptuni. 4B: Lamina width for P. neptuni. 4C: Lamina length for Eotrigonobalanus furcinervis. 4D: Lamina width for E. furcinervis. 4E: Lamina length for Daphnogene cinnamomifolia. 4F: Lamina width for D. cinnamomifolia. The boxes span the $50 \%$ interquartile. The horizontal lines within the boxes indicate the median values. The "whiskers" mark the highest and lowest values. Outliers located at a distance of up to 1.5 times the quartile span outside the whiskers are drawn as asterisks, and extreme outliers are drawn as circles. Different minuscule letters indicate statistically significant differences among sites. Colors indicate deposit type. Colors indicate deposit type. Green: fluviatile. Red: volcanic. Blue: marine. Lines delimit age groups. LE: Late Eocene. EO: Early Oligocene. LO: Late Oligocene. EM: Early Miocene. For site numbers and dating see Table 1.

differences for Platanus neptuni (Figure 6A) and Daphnogene cinnamomifolia (Figure 6E). However, centroid data are significantly different for both late Oligocene sites in P. neptuni (Figure 6A). Both $P$. neptuni (Figure 6A) and D. cinnamomifolia (Figure 6E) show low values for centroid at the Chattian-Aquitanian and the Aquitanian site. All in all, centroid data of $P$. neptuni appear to show a declining trend with decreasing age, and therefore to less ovate leaves (Figure 6A). However, the range of the centroid values is quite narrow, and therefore the change in leaf shape is minor.

As visible from Figure 5 and Figure 6B, 6D and $6 \mathrm{~F}$, and as expected, data in circularity and 

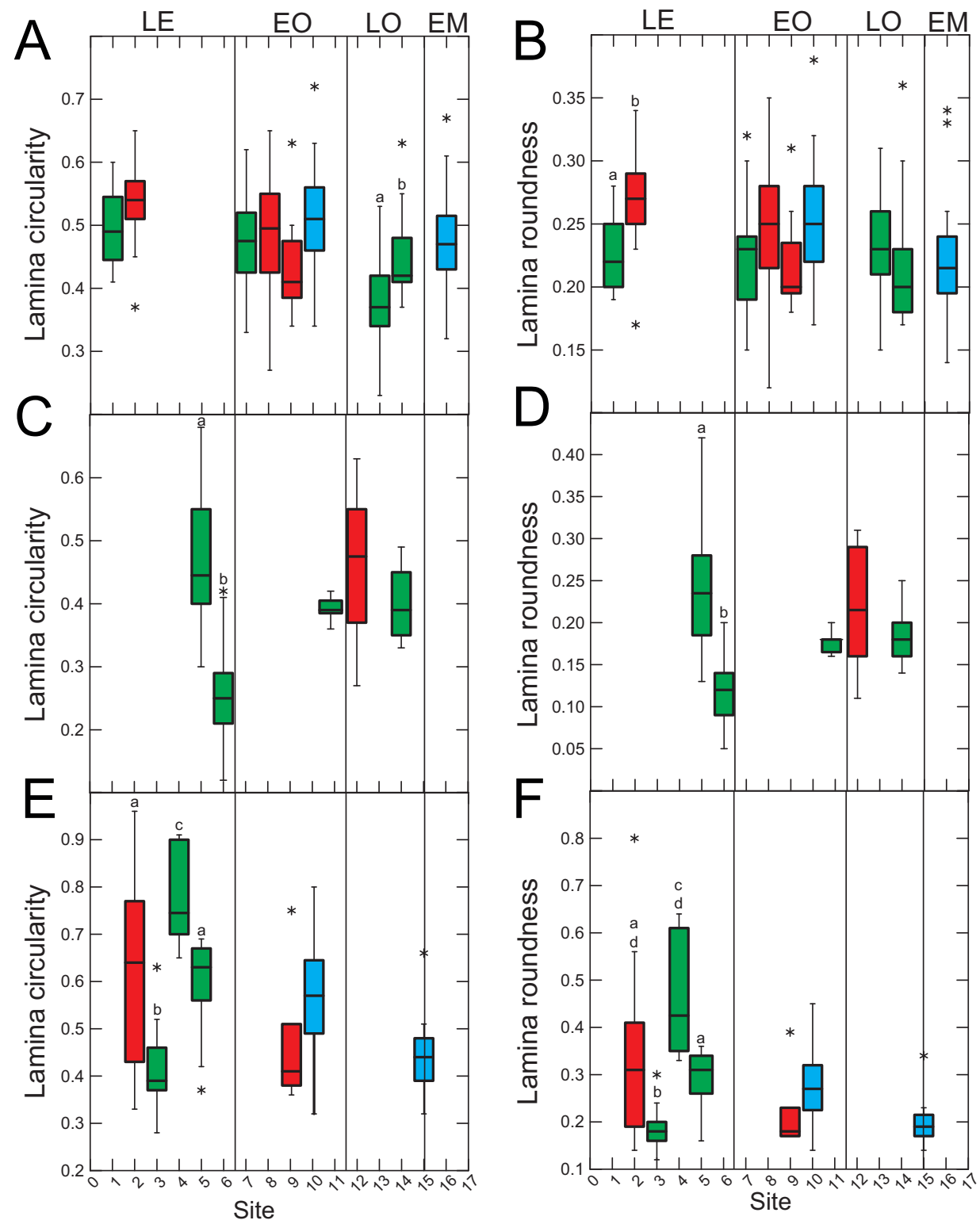

FIGURE 5. Site-specific data for lamina circularity and lamina roundness plotted for each taxon. 5A: Lamina circularity for Platanus neptuni. 5B: Lamina roundness for P. neptuni. 5C: Lamina circularity for Eotrigonobalanus furcinervis. 5D: Lamina roundness for $E$. furcinervis. 5E: Lamina circularity for Daphnogene cinnamomifolia. 5F: Lamina roundness for D. cinnamomifolia. The boxes span the $50 \%$ interquartile. The horizontal lines within the boxes indicate the median values. The "whiskers" mark the highest and lowest values. Outliers located at a distance of up to 1.5 times the quartile span outside the whiskers are drawn as asterisks, and extreme outliers are drawn as circles. Different minuscule letters indicate statistically significant differences among sites. Colors indicate deposit type. Colors indicate deposit type. Green: fluviatile. Red: volcanic. Blue: marine. Lines delimit age groups. LE: Late Eocene. EO: Early Oligocene. LO: Late Oligocene. EM: Early Miocene. For site numbers and dating see Table 1.

roundness tend to be inversely related to LWR data. No relationship could be detected between LCE and circularity and/or roundness (data not shown).

Discriminant analysis (Figure 7) shows that the three taxa form consistent groups which are quite well separated, particularly for the Eocene, despite some overlapping. For the Oligocene, overlapping is stronger, meaning that the considered leaf traits become more similar for the three taxa. The reasons for this result are unclear. Possibly, the niches occupied by the three taxa over- 

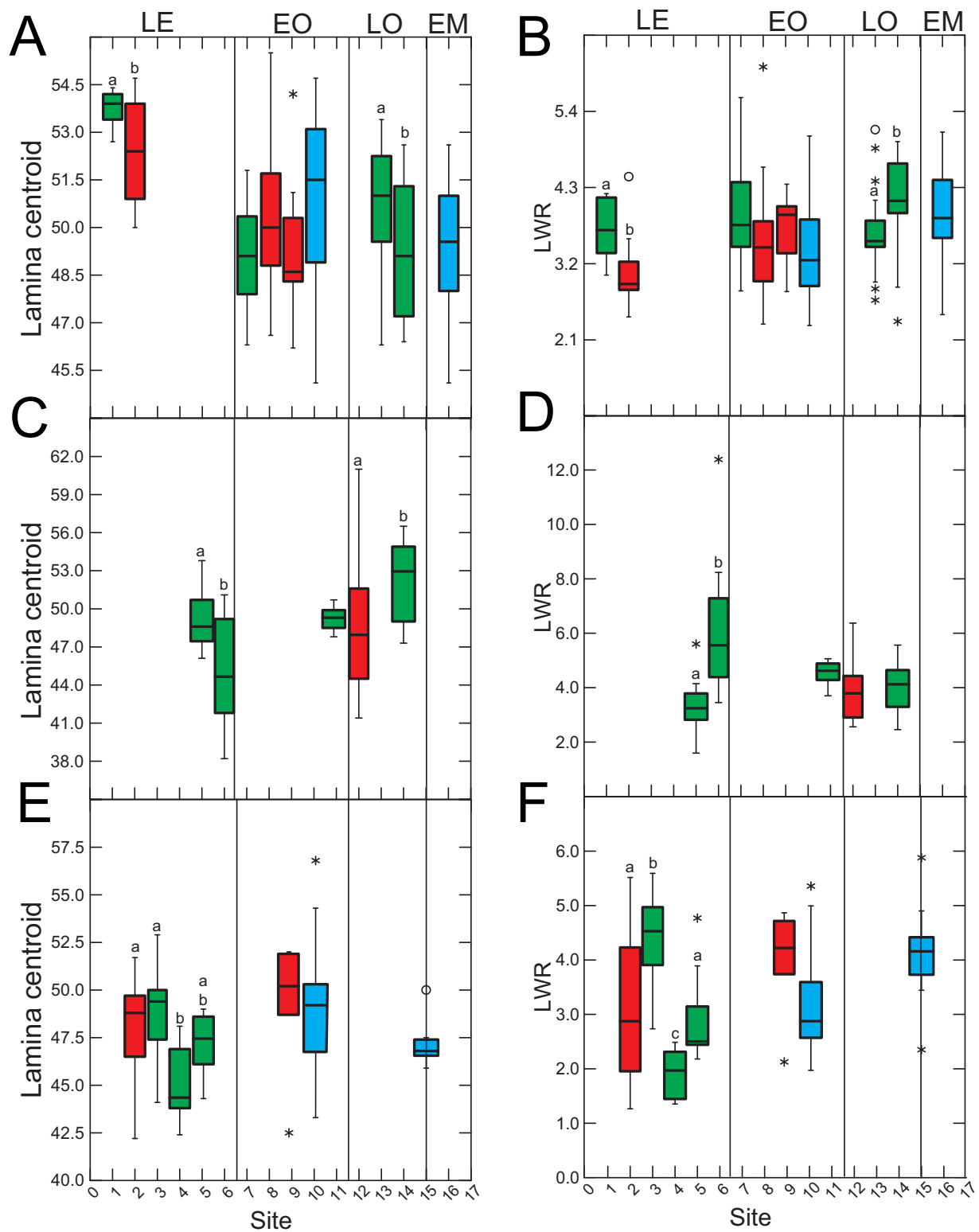

FIGURE 6. Site-specific data for lamina centroid and leaf length-to-width ratio (LWR) plotted for each taxon. 6A: Lamina centroid for Platanus neptuni. 6B: LWR for P. neptuni. 6C: Lamina centroid for Eotrigonobalanus furcinervis. 6D: LWR for E. furcinervis. 6E: Lamina centroid for Daphnogene cinnamomifolia. 6F: LWR for D. cinnamomifolia. The boxes span the $50 \%$ interquartile. The horizontal lines within the boxes indicate the median values. The "whiskers" mark the highest and lowest values. Outliers located at a distance of up to 1.5 times the quartile span outside the whiskers are drawn as asterisks, and extreme outliers are drawn as circles. Different minuscule letters indicate statistically significant differences among sites. Colors indicate deposit type. Colors indicate deposit type. Green: fluviatile. Red: volcanic. Blue: marine. Lines delimit age groups. LE: Late Eocene. EO: Early Oligocene. LO: Late Oligocene. EM: Early Miocene. For site numbers and dating see Table 1.

lapped more during the Oligocene, but this is purely conjectural.

\section{DISCUSSION}

\section{Trait Variability and Possible Drivers}

Intraspecific variability of morphometric leaf traits can be high, particularly for leaf size-related traits, and PI values found in this study are similar 

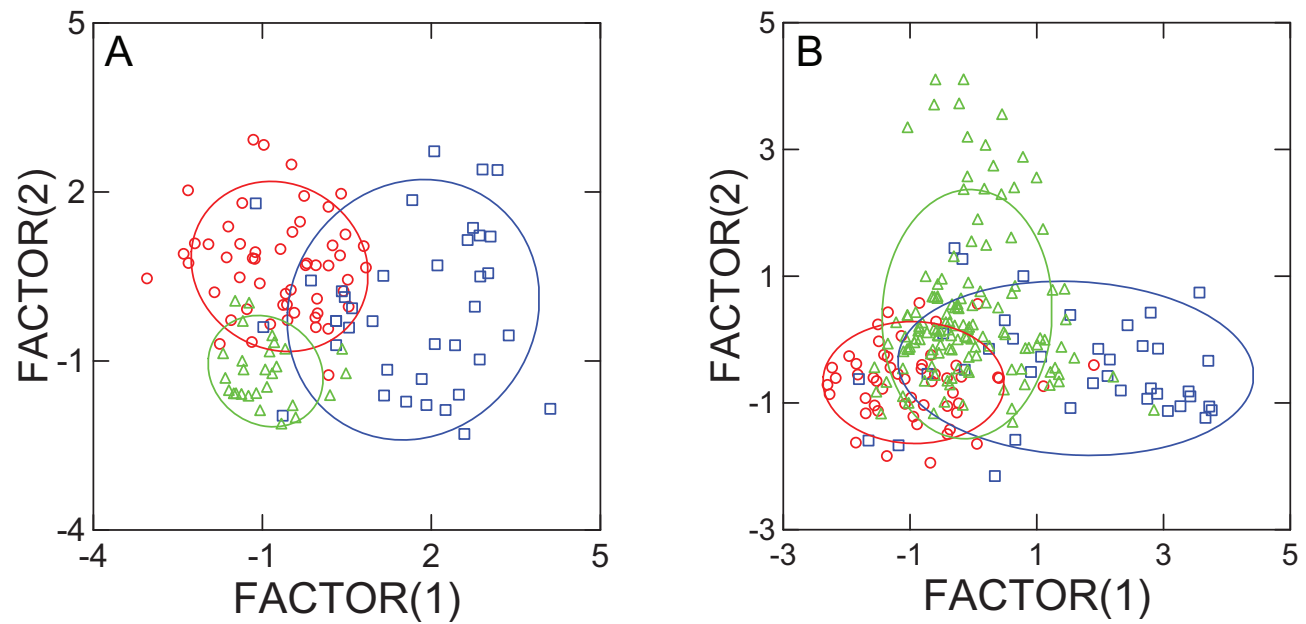

FIGURE 7. Age-specific discriminant analysis using all morphometric parameters for all sites. 7A: Eocene. 7B: Oligocene. Triangles: Platanus neptuni. Squares: Eotrigonobalanus furcinervis. Circles: Daphnogene cinnamomifolia.

to values found for extant taxa (Günthardt-Goerg et al., 2013; Richardson et al., 2013) (Figure 2). Intraspecific variability, expressed as PI, varied substantially between sites, which may be caused by site-specific environmental conditions (GünthardtGoerg et al., 2013). Data availability does, however, also affect PI because a certain minimum number of data are required to assess PI. Sites with fewer leaves are therefore expected to provide a more limited insight into variability than sites with a higher number of leaves. Despite this caveat, in this study sites with a lower number of leaves also show PI values which are quite similar to modern data. Although PI is quite high for many traits, the trait spaces appear to be confined to taxon-specific morphospaces during the whole considered time frame, as is also indicated by Figures 3-7. Just for leaf size-related data of Platanus neptuni data from the Aquitanian are outside the range of the older data sets: $P$. neptuni leaves from the Aquitanian site Linz tend to definitely larger leaves compared to all other sites. However, also in this case, leaf shape does not change, as is indicated by LWR and LCE data. This indicates that size-related parameters, lamina area, perimeter, width and length, change mostly into the same direction, which is also valid for the other two taxa. The site Profen-Schwerzau is exceptional, showing an extremely low $\mathrm{PI}$. It is, however, quite possible that the Profen-Schwerzau PI is not just an artifact due to low data availability, as will be discussed in the last section.

Intraspecific and sub-individual plastic responses to environment are often considered as having an adaptive value itself, because the indi- vidual - or the ecotype - is able to respond adequately to immediate circumstances (Dudley, 2004). Large leaves supposedly signal high humidity levels due to their high water demand. However, other factors are also involved. Plants with large leaves tend to occur preferentially not only in more humid habitats, but are also more frequent under warmer conditions. These plants also require sufficient nutrient availability and are also more common under lower irradiation (Givnish, 1984; McDonald et al., 2003; Nicotra et al., 2011; Peppe et al., 2011; Wright et al., 2017). The high scatter of global data, such as that collected by Wright et al. (2017) indicates that the influence of environment on leaf size is even more complex. For example, Traiser et al. (2005) found for data for woody plants of Europe, that large angiosperm leaves are not uncommon at higher latitudes, possibly to facilitate leaf heating during a cool spring to promote photosynthesis in deciduous taxa (Okajima et al., 2012). Additionally, low angles of incident light may promote the occurrence of larger leaves as was suggested for the Paleogene Arctic mixed broadleaved forests (Herman, 1994).

For evergreen leaves, the lamina should be small and xerophytic in climates with winter freezing, because the common formation of substantial amounts of extracellular ice within tissues of frost hardy plants strongly dehydrates living cells (Hacker and Neuner, 2007; Konrad et al., 2019). Also, freezing-induced water stress can occur because it is not possible for plants to absorb water from frozen soils (Tranquilini, 1982). In fact, Reichgelt et al. (2017) interpreted smaller leaf sizes in Miocene floras from New Zealand, compared to 
extant vegetation, as possibly being caused by lower temperatures and higher probability for winter freezing.

Intraspecific responses of leaf size to environment are also not clear-cut. For example, temperature-caused changes in leaf size found by McKee et al. (2019) for different extant species were quite heterogeneous. Xu et al. (2012) reported a significant increase in lamina size for experimentally warmed Betula utilis, while four extant Nothofagus species studied by Richardson et al. (2013) revealed a slightly positive correlation between leaf size and temperature which was, however, statistically not significant. Trait variability in response to environment can be complex because different environmental parameters acting upon one trait can elicit changes in different directions. The combined total response as a result of two and more factors cannot be derived from the isolated responses to each single factor (Valladares et al., 2007). Additionally, leaf traits are often correlated with each other (Yang et al., 2015).

Leaf size, for instance, is affected by a number of environmental factors, with complex outcomes (Dolph and Dilcher, 1980; Fonseca et al., 2000; McDonald et al., 2003; Carlson et al., 2015; Tozer et al., 2015; Wright et al., 2017). For example, a study showed that leaf size of Fagus sylvatica in a temperate forest increased with declining precipitation along a humidity transect (Meier and Leuschner, 2008). This result was contrary to expectation, because leaf expansion is strongly negative affected by water stress and leaf size is therefore expected to decline under lower humidity (Bradford and Hsiao, 1982). These observed sitespecific differences in leaf size, however, were shown to be driven by conditions in spring when leaves expanded and when humidity was not substantially limited (Meier and Leuschner, 2008). Since the sites with higher summer drought were also warmer during spring, the positive correlation between leaf size and spring temperature was causal while the seemingly negative correlation of leaf size with annual precipitation was a side effect (Meier and Leuschner, 2008). Also, nutrient availability has to be considered. Schneider (2004) reported a lower average leaf size in fossil Magnolia liblarense from Miocene lignites in eastern Germany compared to leaves of the same species from fluvial assemblages, suggesting lower nutrient availability as possible factor leading to smaller leaves in the former habitat.

In previous studies, the correlation between circularity and temperature was reported to be pos- itive, when floras from different areas were compared (Huff et al., 2003), and the same was observed for a global data set (Peppe et al., 2011). Circularity was also demonstrated to show a plastic response to temperature (Huff et al., 2003; Royer et al., 2008; Royer et al., 2009; Peppe et al., 2011; McKee et al., 2019). For circularity, possible adaptive benefits are even less clear than for lamina size. For lobed and toothed leaves, the rounding of lobes and leaf teeth obviously contribute substantially to the plastic increase in circularity (Royer et al., 2008; Royer et al., 2009; McKee et al., 2019).

None of the taxa considered in this study is lobed, and one taxon is entire-margined, but all showed significant variation in circularity. Obviously, changes in circularity of the considered taxa are connected to changes in LWR, as shown by Figure 8, which shows the taxon-specific circularity data plotted against LWR. Clearly, an increasing LWR leads to lower circularity (Figure 8 ). In Figure 8 , also the relationship between circularity and length-to-width ratio of an ellipse is included, which is quite closely tracked by the taxon-specific data collected in this study. This is particularly the case for Daphnogene cinnamomifolia, whereas the data of Platanus neptuni and Eotrigonobalanus furcinervis are located somewhat below the ellipse graph. This is very likely due to the leaf teeth of $P$. neptuni and $E$. furcinervis and to their more spindle-shaped lamina, reducing their lamina area relative to an elliptic shape showing the same width.

Occasionally, a high LWR is explained as beneficial against overheating under high temperature (Parkhurst and Loucks, 1972). However, leaf temperature depends on absolute width, not on LWR (Leigh et al., 2016). Nevertheless, LWR is climatesensitive, although in a complex way. In CLAMP, LWR is used in the form of separate LWR classes, which were found to be particularly common in certain environments, in combination with other traits. For example, long and toothed leaves appear to be characteristic for riparian vegetation (Wolfe, 1993). With respect to spatial patterns within European vegetation, Traiser et al. (2005) observed that short and wide leaves are most common under northeastern continental conditions whereas lengthy and narrow leaves occur preferentially in Mediterranean regions, together with smaller leaf size. LWR is also affected by an acuminate tip: the more acute the tip, the longer the main axis of the leaf. For tropical Africa, Jacobs (1999) observed a positive correlation of LWR with precipitation, due to higher occurrence of acuminate tips under high humidity. Site-specific LWR relationships of differ- 


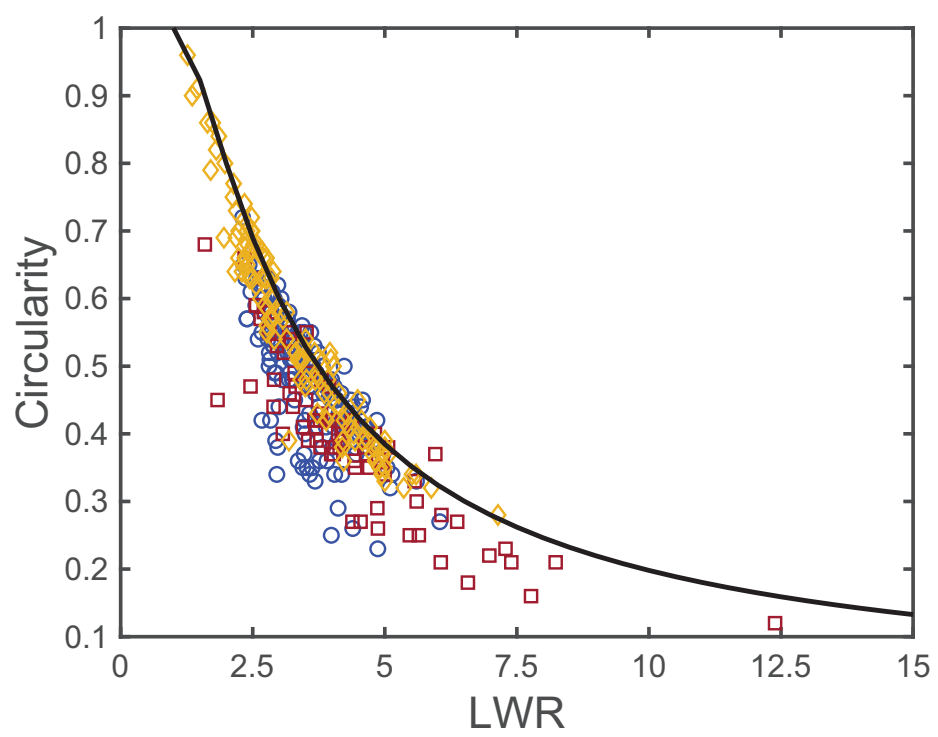

FIGURE 8. Circularity plotted against LWR. Blue circles: Platanus neptuni. Red squares: Eotrigonobalanus furcinervis. Yellow diamonds: Daphnogene cinnamomifolia. Black line: Relationship between circularity and length-towidth ratio of an ellipse. Please note that this relationship was calculated by using an approximate equation for the perimeter of an ellipse, which causes the slight deflection of the curve for high circularity values. As approximation, the following equation for the ellipse perimeter $(E P)$ was used: $E P=\pi^{*}\left[2 *\left(a^{2}+b^{2}\right)^{1 / 2}\right]$.

ent floras with climate, which are driven largely by vegetation composition, appear therefore to be discontinuous and influenced differentially by various combinations of factors.

With respect to intraspecific responses, a positive correlation between LWR and temperature appears to be not uncommon. For example, Xu et al. (2012) reported a decrease of LWR under experimental warming in Betula utilis. A similar response was observed by Günthardt-Goerg et al. (2013) for experimental warming of various oak species and also for most species considered by McKee et al. (2019). In many cases, however, the response of LWR to warming was moderate and not significant.

\section{Trait-Variability and Palaeoclimate}

Despite the various caveats discussed above, trends in circularity, LWR and leaf size of Platanus neptuni and Daphnogene cinnamomifolia obtained in the present study appear to be quite consistent with site-specific CLAMP results (Appendix 2), at least for the Oligocene and early Miocene. For example, the data obtained in this study for circularity - and also leaf size - corroborate the notion of the Rupelian site Rauenberg as a quite warm locality, and the late Chattian site Witznitz-WC as warmer than the early Chattian Borna-Ost-Bock-
witz-TC site, as was also discussed by Kovar-Eder (2016) and Moraweck et al. (2019). For the early Miocene, warmer conditions than for the Chattian sites are indicated by leaf size and circularity data of $P$. neptuni for the Linz localities, also in accordance with CLAMP. For the younger Eferding site (for which no CLAMP results are available), however, $D$. cinnamomifolia shows circularity values similar to the Chattian sites.

It should be noted that comparing stratigraphic trends, as observed in the present study, with CLAMP climate results does not represent a "test" of CLAMP. Firstly, this is not possible with just three taxa. Secondly, independent climate data would be necessary. What this comparison - illustrated in Appendix 2 - shows, however, is that the plastic changes of our taxa are largely consistent with available climate data for the Oligocene and Miocene, but in a species-specific manner, as expected.

Climate was probably quite variable during the Oligocene, with various minor cooling and warming events (Li et al., 2018). For Central Europe, there is evidence for a warmer Rupelian and cooling during the Chattian (Li et al., 2018). Evidence for a warming event at the Rupelian-Chattian boundary in the southern North Sea Basin was found by De Man and Van Simaeys (2004), based on marine 
proxies, which also indicate a cooling during the later Chattian. Pollen based data and $\delta^{18} \mathrm{O}$ values of fossil bivalve shells and shark teeth from Western Germany also indicate a decrease of terrestrial and sea-surface temperatures during the Chattian, followed by warming towards the Oligocene-Miocene transition (Walliser et al., 2016).

Palaeoclimate data for the Paleogene and Neogene are, however, heterogeneous and vary geographically as demonstrated, for example, by data of Teodoridis and Kvaček (2015) for Central Europe, which are based on CLAMP and CA and indicate, all in all, a possible warming after the EOT during the early Oligocene, followed by cooling towards the Oligocene-Miocene boundary. Sitespecific climate can also be strongly affected by geographic position and local conditions, and distinct spatial heterogeneity is to be expected reflecting meso-climate. For instance, distance to shorelines will have an effect, due to the marine influence ( $\mathrm{Li}$ et al., 2018). The region of Linz, for example, was influenced by the warm Paratethys (Kvaček et al., 2006) and Rauenberg was situated at the margin of the Upper Rhine graben, which was a marine connection between the Paratethys and the North Sea whereas the locations of the Leipzig Embayment were exposed to the influence of the cooler North Sea (Moraweck et al., 2019). In particular, the lower Oligocene Rauenberg flora contains some subtropical Eocene relics (Actinodaphne pseudogermari, Doliostrobus taxiformis) and thermophilous species (Ceratozamia floersheimensis) that either disappeared, or were never present, in coeval floras of the coastal North Sea lowlands of the Leipzig Embayment (KovarEder 2016).

The warming signal shown by circularity data of Platanus neptuni (and the CLAMP data set) for the Linz sites, when compared to the late Oligocene data of the Leipzig Embayment localities, may therefore just reflect regional climate (Moraweck et al., 2019). The low circularity value of Daphnogene cinnamomifolia for the somewhat older Eferding site, which was also situated at the northern margin of the Paratethys, may reflect the cooling event at the Oligocene-Miocene boundary (which represents the Mi-1 glaciation event) (Miller et al., 1998; Lear et al., 2004; Larsson et al., 2010; Li et al., 2018).

When considering palaeobotanical data, there are always various biases to consider that afflict information from fossil material on different levels, such as taphonomic filtering and sampling biases, which are discussed in depth in various studies (for example, Ferguson, 1985; Steart et al., 2002; Kovar-Eder et al., 2008; and Moraweck et al., 2019). Despite these limitations and caveats, however, the presented data for circularity, as well as for leaf size and LWR, are partially in quite good agreement with site-specific CLAMP data as well as with general proxy-indicated trends for Oligocene climate, such as a quite warm Rupelian, and cooler conditions in the Chattian.

\section{High Trait Variability for the Eocene}

The most conspicuous feature of the data set, however, is the strong variability of morphometric data for the Eocene, particularly shown by Daphnogene cinnamomifolia, but also indicated by the more limited Eocene data of Platanus neptuni. Statistically significant differences are most frequent for late Eocene material in all considered taxa. For example, in $D$. cinnamomifolia, which provided material for four late Eocene sites, leaf size peaked distinctly for two Priabonian data sets whereas leaf size for the two other localities is markedly lower (Figure 3F). In many cases of the collected data set, the late Eocene variability of the considered leaf traits largely covers the total range of variability over the entire considered time interval.

The values for leaf size-related data of Platanus neptuni at the Profen-Schwerzau site are conspicuously low. It is possible that this result is due to the quite limited number of available suitable leaves from this site. With respect to climate, MAT is in the range of the other Eocene sites, whereas precipitation is high (Appendix 2). High precipitation, however, causes leaching of nutrients (Givnish, 2002) which in turn may promote smaller leaf size due to lower nutrient availability. Furthermore, another conspicuous feature of the ProfenSchwerzau site is the very low PI, the lowest for all other sites and taxa (Figure 2). As shown by Balaguer et al. (2001), homogeneous light conditions, meaning more open landscapes, can lead to low plasticity. Furthermore, leaves acclimated to high irradiation may tend to smaller lamina size (Scoffoni et al., 2015). It is therefore possible, that specific local conditions at the Profen-Schwerzau site caused low leaf size and low intraspecific variability.

The late Eocene was a period of global cooling, which is also broadly reflected by plant proxies and vegetational composition. The turnover of vegetation in Central Europe from broadleaved evergreen forests towards mixed mesophytic forests started well before the EOT during the late Priabonian (Kvaček et al., 2014; Teodoridis and 
Kvaček, 2015; Utescher et al., 2015; Kunzmann et al., 2016; Pound and Salzmann, 2017). Cooling predominantly increased temperature seasonality (Mosbrugger et al., 2005; Eldrett et al., 2009). The strong morphometric variability shown by the trait data of the considered species for the late Eocene material appears to be not consistent with available CLAMP temperature proxy data, which show mostly moderate variations (Appendix 2). Moreover, trends in lamina area, circularity and LWR data for the late Eocene data appear to be in contradiction to temperature trends indicated by CLAMP (Appendix 2). However, precipitation data indicated by CLAMP results - when available show a quite high variation for the considered Eocene sites (Appendix 2). There is evidence that in addition to cooling the pattern and amount of precipitation changed in Central Europe, with precipitation becoming more seasonal as also indicated by the palaeoclimate reconstruction results (Moraweck et al., 2015). This is also indicated by sediment data from northwestern central Europe, featuring changes in mineral composition as well as content of $\mathrm{N}$-isotopes (Tramoy et al., 2016). These data provide evidence for a transition to drier conditions from the EOT onwards and also a distinct event, namely a dip towards cooler and/or drier conditions during the Priabonian (Tramoy et al., 2016). Possibly, also other soil conditions than soil moisture content changed during this time, adding another confounding factor because many leaf traits are affected by nutrients.

From these considerations, it appears to be quite possible that the high morphometric variability shown by two of the three considered taxa for the late Eocene data indicate a general environmental instability during this period of major climate transition. Changing $\mathrm{CO}_{2}$ values may have also possibly affected leaf traits indirectly, because stomatal conductance, and therefore water demand, is expected to be inversely correlated with atmospheric $\mathrm{CO}_{2}$, as shown by various data and modeling results (Ainsworth and Rogers, 2007; Konrad et al., 2008; Leakey et al., 2009). In fact, elevated $\mathrm{CO}_{2}$ was demonstrated to decrease the water demand of a mature forest (Bader et al., 2013), albeit the detailed ecophysiological ramifications of changing $\mathrm{CO}_{2}$ on plants in natural habitats are complex (Donohue et al., 2017).

With respect to deposit type, the data do not allow for drawing definite conclusions on a possibly specific habitat signal. In Moraweck et al. (2019), leaf size-related data indicated a possible trend for larger leaves in marine deposits, likely caused by the accumulation of leaves of different habitats in these allochthonous assemblages and/or the marine influence on climate. This effect on morphometric leaf traits is much less distinct in the present data set. However, PI appears to tend to higher values in marine deposits (Figure 2). Also, Moraweck et al. (2019) found - for micromorphological traits (stomata, trichome densities) of Platanus neptuni - evidence for higher intraspecific variability in allochthonous assemblages. This may be explained by the heterogeneous composition of leaf material, originating from different sites from the hinterland with different local climate as well as possibly mixing leaves from different ecotypes. However, more data are required to better pinpoint this hypothetical effect.

\section{CONCLUSIONS}

All three considered fossil-species show various site-specific and significant differences, for leaf size-related traits, as well as for leaf shape-related traits. For the considered time interval, the data vary mostly within a taxon-specific range, and therefore within a taxon-specific morphospace. There is no indication for trends with respect to deposit type and therefore no specific deposit-habitat relationships. However, data from marine and therefore allochthonous deposits show the highest plasticity, probably due to the accumulation of heterogeneous plant material from different growing sites.

For the Oligocene and Miocene, the results are mostly consistent with palaeo-temperature data and here in particular for circularity data. Since circularity and length/width ratios are closely related for non-lobed taxa, as were considered in this study, the results confirm both traits as useful indicators for temperature. The high variability of various traits for the Eocene are, however, difficult to attribute to temperature. Rather, the considerable variability of Eocene trait data may be explained by environmental instability during the climate transition phase, such as changing precipitation patterns.

\section{ACKNOWLEDGMENTS}

This research was supported and financed by a grant of the Volkswagen Foundation to A.R.-N., L.K., J.K. and J.K.-E., within the program "Research in Museums" (Refs. 87139, 87160, 87160-1). Many thanks go to K. Moraweck (Dresden) for contributing morphometric data and helpful discussions. We thank R. Spicer (The Open Uni- 
versity), T. Denk (Naturhistoriska Riksmuseet, Stockholm) and an anonymous reviewer for their constructive comments. We also thank J. Nebel- sick (University of Tübingen) for critically reading the English manuscript.

\section{REFERENCES}

Ainsworth, E.A. and Rogers, A. 2007. The response of photosynthesis and stomatal conductance to rising $\left[\mathrm{CO}_{2}\right]$ : mechanisms and environmental interactions. Plant, Cell and Environment, 30:258-270. https://doi.org/10.1111/j.1365-3040.2007.01641.x

Akhmetiev, M., Walther, H., and Kvaček, Z. 2009. Mid-latitude Paleogene flora of Eurasia bound to volcanic settings and palaeoclimatic events - experience obtained from the Far East of Russia (Sikhote-Alin) and Central Europe (Bohemian Massif). Acta Musei Nationalis Pragae, Series B-Historia Naturalis, 65:61-129.

Bader, M.K.F., Leuzinger, S., Keel, S.G., Siegwolf, R.T.W., Hagedorn, F., Schleppi, P., and Körner, C. 2013. Central European hardwood trees in a high- $\mathrm{CO}_{2}$ future: synthesis of an 8year forest canopy $\mathrm{CO}_{2}$ enrichment project. Journal of Ecology, 101(6):1509-1519. https://doi.org/10.1111/1365-2745.12149

Balaguer, L., Martínez-Ferri, E., Valladares, F., Pérez-Corona, M., Baquedano, F., Castillo, F., and Manrique, E. 2001. Population divergence in the plasticity of the response of Quercus coccifera to the light environment. Functional Ecology, 15:124-135. https://doi.org/10.1046/j.1365-2435.2001.00505.x

Bellon, H., Bůžek, Č., Gaudant, J., Kvaček, Z., and Walther, H. 1998. The České Středohoří magmatic complex in Northern Bohemia ${ }^{40} \mathrm{~K}-40 \mathrm{Ar}$ ages for volcanism and biostratigraphy of the Cenozoic freshwater formations. Newsletter on Stratigraphy, 36:77-103. https://doi.org/10.1127/nos/36/1998/77

Bradford, K. and Hsiao, T. 1982. Physiological responses to moderate water stress, p. 263-324. In Lange, O.L., Nobel, P.S., Osmond, C.B., and Ziegler, H. (eds.), Physiological Plant Ecology II. Springer, Berlin, Heidelberg, New York.

Cajz, V. 2000. Proposal of lithostratigraphy for the České středohoří Mts. volcanics. Věstník Českého geologického ústavu, 75:7-16.

Cajz, V., Vokurka, K., Balogh, K., Lang, M., and Ulrych, J. 1999. The České středohoří Mts.: volcanostratigraphy and geochemistry. GeoLines, 9:21-28.

Carlson, J.E., Adams, C.A., and Holsinger, K.E. 2015. Intraspecific variation in stomatal traits, leaf traits and physiology reflects adaptation along aridity gradients in a South African shrub. Annals of Botany, 117(1):195-207. https://doi.org/10.1093/aob/mcv146

Chitwood, D.H. and Sinha, N.R. 2016. Evolutionary and environmental forces sculpting leaf development. Current Biology, 26(7):R297-R306. https://doi.org/10.1016/j.cub.2016.02.033

De Man, E. and Van Simaeys, S. 2004. Late Oligocene warming event in the southern North Sea basin: benthic foraminifera as paleotemperature proxies. Netherlands Journal of Geosciences, 83(3):227-239. https://doi.org/10.1017/S0016774600020291

Dolph, G.E. and Dilcher, D.L. 1980. Variation in leaf size with respect to climate in Costa Rica. Biotropica, 12(2):91-99.

Donohue, R.J., Roderick, M.L., McVicar, T.R., and Yang, Y. 2017. A simple hypothesis of how leaf and canopy?level transpiration and assimilation respond to elevated $\mathrm{CO} 2$ reveals distinct response patterns between disturbed and undisturbed vegetation. Journal of Geophysical Research: Biogeosciences, 122(1):168-184. https://doi.org/10.1002/2016JG003505

Dudley, S. 2004. The functional ecology of phenotypic plasticity in plants, p. 151-172. In DeWitt, T.J., Scheiner, S.M., and Brody, H.M. (eds.), Phenotypic Plasticity: Functional and Conceptual Approaches. Oxford University Press, Oxford.

Eldrett, J.S., Greenwood, D.R., Harding, I.C., and Huber, M. 2009. Increased seasonality through the Eocene to Oligocene transition in northern high latitudes. Nature, 459(7249):969973. https://doi.org/10.1038/nature08069 
Enrique, G., Olmo, M., Poorter, H., Ubera, J.L., and Villar, R. 2016. Leaf mass per area (LMA) and its relationship with leaf structure and anatomy in 34 Mediterranean woody species along a water availability gradient. PloS one, 11(2). https://doi.org/10.1371/journal.pone.0148788

Ferguson, D.K. 1985. The origin of leaf-assemblages - new light on an old problem. Review of Palaeobotany and Palynology, 46:117-188. https://doi.org/10.1016/0034-6667(85)90041-7

Fonseca, C.R., Overton, J.M., Collins, B., and Westoby, M. 2000. Shifts in trait-combinations along rainfall and phosphorus gradients. Journal of Ecology, 88(6):964-977. https://doi.org/10.1046/j.1365-2745.2000.00506.x

Givnish, T. 2002. Adaptive significance of evergreen vs. deciduous leaves: solving the triple paradox. Silva Fennica, 36(3):703-743. https://doi.org/10.14214/sf.535

Givnish, T.J. 1984. Physiological ecology of plants of the wet tropics, p. 51-84. In Medina, E., Mooney, H.A., and Vázquez-Yánes, C. (eds.), Proceedings of an International Symposium held in Oxatepec and Los Tuxtlas, Mexico, June 29 to July 6, 1983. Springer Netherlands, Dordrecht.

Goth, K., Suhr, P., and Schulz, R. 2003. Zwei Forschungsbohrungen in das verdeckte Maar von Baruth (Sachsen). Zeitschrift für angewandte Geologie, 49:9-17.

Grimm, K. I., Grimm, M., Kothe, A., and Schindler, T. 2002. Der „Rupelton" (Rupelium, Oligozän) der Tongrube Bott-Eder bei Rauenberg (Oberrheingraben, Deutschland). Courier Forschungsinstitut Senckenberg, 237:229-254.

Grímsson, F., Grimm, G.W., Zetter, R., and Denk, T. 2016. Cretaceous and Paleogene Fagaceae from North America and Greenland: evidence for a Late Cretaceous split between Fagus and the remaining Fagaceae. Acta Palaeobotanica, 56(2):247-305.

Grunert, P., Harzhauser, M., Rögl, F., Sachsenhofer, R., Gratzer, R., Soliman, A., and Piller, W.E. 2010. Oceanographic conditions as a trigger for the formation of an Early Miocene (Aquitanian) Konservat-Lagerstätte in the Central Paratethys Sea. Palaeogeography, Palaeoclimatology, Palaeoecology, 292(3-4):425-442. https://doi.org/10.1016/j.palaeo.2010.04.001

Grunert, P., Auer, G., Harzhauser, M., and Piller, W.E. 2015. Stratigraphic constraints for the upper Oligocene to lower Miocene Puchkirchen Group (North Alpine Foreland Basin, Central Paratethys). Newsletters on Stratigraphy, 48(1):111-133. https://doi.org/10.1127/nos/2014/0056

Günthardt?Goerg, M.S., Kuster, T.M., Arend, M., and Vollenweider, P. 2013. Foliage response of young central European oaks to air warming, drought and soil type. Plant Biology, 15:185197. https://doi.org/10.1111/j.1438-8677.2012.00665.x

Hacker, J. and Neuner, G. 2007. Ice propagation in plants visualized at the tissue level by infrared differential thermal analysis (IDTA). Tree Physiology, 27(12):1661-1670. https://doi.org/10.1093/treephys/27.12.1661

Harris, E.B. and Arens, N.C. 2016. A mid-Cretaceous angiosperm-dominated macroflora from the Cedar Mountain Formation of Utah, USA. Journal of Paleontology, 90(4):640-662.

Herman, A.B. 1994. Late Cretaceous Arctic platanoids and high latitude climate, p. 151-159. In Boulter, M.C. and Fisher, H.C. (eds.), Cenozoic Plants and Climates of the Arctic (NATO ASI Ser., I 27). Springer, Berlin.

Hinojosa, L.F., Pérez, F., Gaxiola, A., and Sandoval, I. 2011. Historical and phylogenetic constraints on the incidence of entire leaf margins: insights from a new South American model. Global Ecology and Biogeography, 20(3):380-390. https://doi.org/10.1111/j.1466-8238.2010.00595.x

Hren, M.T., Sheldon, N.D., Grimes, S.T., Collinson, M.E., Hooker, J.J., Bugler, M., and Lohmann, K.C. 2013. Terrestrial cooling in Northern Europe during the Eocene-Oligocene transition. Proceedings of the National Academy of Sciences, 110(19):7562-7567. https://doi.org/10.1073/pnas.1210930110

Huff, P.M., Wilf, P., and Azumah, E.J. 2003. Digital future for paleoclimate estimation from fossil leaves? Preliminary results. Palaios, 18(3):266-274. https://doi.org/10.1669/0883-1351(2003)018\%3C0266:DFFPEF\%3E2.0.CO;2

Hufford, K.M. and Mazer, S.J. 2003. Plant ecotypes: genetic differentiation in the age of ecological restoration. Trends in Ecology and Evolution, 18(3):147-155.

https://doi.org/10.1016/S0169-5347(03)00002-8 
Hutchinson, D.K., Coxall, H.K., Lunt, D.J., Steinthorsdottir, M., de Boer, A.M., Baatsen, M., von der Heydt, A., Huber, M., Kennedy-Asser, A.T., Kunzmann, L., Ladant, J.-B., Lear, C.H., Moraweck, K., Pearson, P.N., Piga, E., Pound, M.J., Salzmann, U., Scher, H.D., Sijp, W.P., Śliwińska, K.K., Wilson, P.A., and Zhang, Z. 2020. The Eocene-Oligocene transition: a review of marine and terrestrial proxy data, models and model-data comparisons. Climate of the Past (Discussion papers). https://doi.org/10.5194/cp-2020-68

Jacobs, B.F. 1999. Estimation of rainfall variables from leaf characters in tropical Africa. Palaeogeography, Palaeoclimatology, Palaeoecology, 145(1-3):231-250. https://doi.org/10.1016/S0031-0182(98)00102-3

Jacobs, B.F. and Herendeen, P.S. 2004. Eocene dry climate and woodland vegetation in tropical Africa reconstructed from fossil leaves from northern Tanzania. Palaeogeography, Palaeoclimatology, Palaeoecology, 213(1-2):115-123. https://doi.org/10.1016/j.palaeo.2004.07.007

Kikuzawa, K. and Lechowicz, M.J. 2011. Ecology of Leaf Longevity. Springer, Tokyo.

Knobloch, E., Konzalová, M., and Kvaček, Z. 1996. Die obereozäne Flora der Staré SedloSchichtenfolge in Böhmen (Mitteleuropa). Rozpravy Českého geologického ústavu, 49:1260.

Konrad, W., Roth-Nebelsick, A., and Grein, M. 2008. Modelling of stomatal density response to atmospheric $\mathrm{CO}_{2}$. Journal of Theoretical Biology, 253:638-658 https://doi.org/10.1016/j.jtbi.2008.03.032

Konrad, W., Schott, R., and Roth-Nebelsick, A. 2019. A model for extracellular freezing based on observations on Equisetum hyemale. Journal of Theoretical Biology, 478:161-168. https://doi.org/10.1016/j.jtbi.2019.06.023

Kovar-Eder, J. and Berger, J.-P. 1985. Die oberoligozäne Flora von Unter-Rudling bei Eferding in Oberösterreich. Annalen des Naturhistorischen Museums in Wien. Serie A für Mineralogie und Petrographie, Geologie und Paläontologie, Anthropologie und Prähistorie, 89:57-93.

Kovar-Eder, J., Jechorek, H., Kvaček, Z., and Parashiv, V. 2008. The integrated plant record: An essential tool for reconstructing Neogene zonal vegetation in Europe. Palaios, 23:97-111. https://doi.org/10.2110/palo.2006.p06-039r

Kovar-Eder, J. 2016. Early Oligocene plant diversity along the Upper Rhine Graben: the fossil flora of Rauenberg, Germany. Acta Palaeobotanica, 56(2):329. https://doi.org/10.1515/acpa-2016-0011

Kovar, J.B. 1982. Eine Blätter-Flora des Egerien (Ober-Oligozän) aus marinen Sedimenten der zentralen Paratethys im Linzer Raum (Österreich). Beiträge zur Paläontologie von Österreich, 9:1-209.

Kriegel, K. 2001. Untersuchung der Blattmorphologie und Blattanatomie von Eotrigonobalanus furcinervis (Rossmäßler) Walther \& Kvaček und seine Vergesellschaftung mit anderen tertiären Sippen vom Mitteleozän bis Oligo-/Miozän Mitteleuropas. Unpublished Diploma thesis, Technical University Dresden, Dresden, Germany.

Krutzsch, W., Blumenstengel, H., Kiesel, Y., and Rüffle, L. 1992. Paläobotanische Klimagliederung des Alttertiärs (Mitteleozän bis Oberoligozän) in Mitteldeutschland und das Problem der Verknüpfung mariner und kontinentaler Gliederungen (klassische Biostratigraphien - paläobotanisch-ökologische Klimastratigraphie-Evolutions-Stratigraphie der Vertebraten). Neues Jahrbuch fur Geologie und Paläontologie/Abhandlungen, 186:137253.

Krutzsch, W. 2011. Stratigrafie und Klima des Paläogens im Mitteldeutschen Ästuar im Vergleich zur marinen nördlichen Umrahmung. Zeitschrift der Deutschen Gesellschaft für Geowissenschaften 162:19-46.

Kunzmann, L., Kvaček, Z., Teodoridis, V., Müller, C., and Moraweck, K. 2016. Vegetation dynamics of riparian forests in central Europe during the late Eocene. Palaeontographica, Abt. B Palaeophytologica, 295:69-89. https://doi.org/10.1127/palb/295/2016/69

Kvaček, Z. and Knobloch, E. 1967. Zur Nomenklatur der Gattung Daphnogene Ung. und die neue Art Daphnogene pannonica sp. n. Věstník Ústředního ústavu geologického, 41:291294.

Kvaček, Z. and Walther, H. 1989. Revision der mitteleuropäischen tertiären Fagaceen nach blattepidermalen Charakteristiken. III. Dryophyllum Debey ex Saporta und Eotrigonobalanus Walther \& Kvaček gen. nov. Feddes Repertorium, 100:575-560. 
Kvaček, Z. and Walther, H. 1995. The Oligocene volcanic flora of Suletice-Berand near Ústí nad Labem, north Bohemia-a review. Acta Musei Nationalis Pragae, Series B-Historia Naturalis, 50:25-54.

Kvaček, Z. and Walther, H. 1998. The Oligocene volcanic flora of Kundratice near Litoměřice, České Středohoeři volcanic complex, Czech Republic: a review. Acta Musei Nationalis Pragae, Series B, Historia Naturalis, 54:1-42.

Kvaček, Z. and Walther, H. 2003. Reconstruction of vegetation and landscape development during the volcanic activity in the České středohoři Mountains. Geolines, Hibsch Special Volume, 15:60-64.

Kvaček, Z. and Manchester, S. 2004. Vegetative and reproductive structure of the extinct Platanus neptuni from the Tertiary of Europe and relationships within the Platanaceae. Plant Systematics and Evolution, 244:1-29. https://doi.org/10.1007/s00606-003-0082-2

Kvaček, Z., Kováč, M., Kovar-Eder, J., Dolákova, N., Jechorek, H., Parashiv, V., Kováčová, M., and Sliva, L. 2006. Miocene evolution of landscape and vegetation in the Central Paratethys. Geologica Carpathica, 57(4):295-310.

Kvaček, Z., Teodoridis, V., Mach, K., Přikryl, T., and Dvořák 2014. Tracing the Eocene Oligocene transition: a case study from North Bohemia. Bulletin of Geosciences, 89:21-66.

Larcher, W. 2003. Physiological Plant Ecology. Cambridge University Press, Cambridge.

Larsson, L.M., Vajda, V., and Dybkjær, K. 2010. Vegetation and climate in the latest Oligoceneearliest Miocene in Jylland, Denmark. Review of Palaeobotany and Palynology, 159(3):166176. https://doi.org/10.1016/j.revpalbo.2009.12.002

Leakey, A.D.B., Ainsworth, E.A., Bernacchi, C.J., Rogers, A., Long, S.P., and Ort, D.R. 2009. Elevated $\mathrm{CO}_{2}$ effects on plant carbon, nitrogen, and water relations: six important lessons from FACE. Journal of Experimental Botany, 60(10):2859-2876. https://doi.org/10.1093/jxb/erp096

Lear, C.H., Rosenthal, Y., Coxall, H.K., and Wilson, P. 2004. Late Eocene to early Miocene ice sheet dynamics and the global carbon cycle. Paleoceanography, 19(4). https://doi.org/10.1029/2004PA001039

Leigh, A., Sevanto, S., Close, J.D., and Nicotra, A.B. 2016. The influence of leaf size and shape on leaf thermal dynamics: does theory hold up under natural conditions? Plant, Cell and Environment, 40:237-248. https://doi.org/10.1111/pce.12857

Li, S., Xing, Y., Valdes, P.J., Huang, Y., Su, T., Farnsworth, A., Lunt, D.J., Tang, H., Kennedy, A.T., and Zhou, Z. 2018. Oligocene climate signals and forcings in Eurasia revealed by plant macrofossil and modelling results. Gondwana Research, 61:115-127. https://doi.org/10.1016/j.gr.2018.04.015

Little, S.A., Kembel, S.W., and Wilf, P. 2010. Paleotemperature proxies from leaf fossils reinterpreted in light of evolutionary history. PloS one, 5(12):e15161. https://doi.org/10.1371/ journal.pone.0015161

Lowe, A.J., Greenwood, D.R., West, C.K., Galloway, J.M., Sudermann, M., and Reichgelt, T. 2018. Plant community ecology and climate on an upland volcanic landscape during the Early Eocene Climatic Optimum: McAbee Fossil Beds, British Columbia, Canada. Palaeogeography, Palaeoclimatology, Palaeoecology, 511:433-448. https://doi.org/10.1016/j.palaeo.2018.09.010

Mai, D. 1995. Tertiäre Vegetationsgeschichte Europas: Methoden und Ergebnisse. Spektrum Akademischer Verlag, Heidelberg, Germany.

Mai, D. and Walther, H. 1985. Die obereozänen Floren des Weißelster-Beckens (Bezirk Leipzig, DDR). Abhandlungen Staatliches Museum für Mineralogie und Geologie zu Dresden, 33:1260.

Mai, D. and Walter, H. 1991. Die oligozänen und untermiozänen Floren Nordwest-Sachsens und des Bitterfelder Raumes. Abhandlungen Staatliches Museum für Mineralogie und Geologie zu Dresden, 38:1-230.

Manchester, S.R. and Kvaček, Z. 2010. Inflorescences and compound leaves of the extinct Platanus neptuni complex in the Oligocene of Oregon, USA. Acta Palaeobot, 50:5-15.

Maxwell, E.E., Alexander, S., Bechly, G., Eck, K., Frey, E., Grimm, K., Kovar-Eder, J., Mayr, G., Micklich, N., Rasser, M., Roth-Nebelsick, A., Salvador, R.B., Schoch, R.R., Schweigert, G., Stinnesbeck, W., Wolf-Schwenninger, K., and Ziegler, R. 2016. The Rauenberg fossil Lagerstätte (Baden-Württemberg, Germany): A window into early Oligocene marine and coastal ecosystems of Central Europe. Palaeogeography, Palaeoclimatology, Palaeoecology, 463:238-260. https://doi.org/10.1016/j.palaeo.2016.10.002 
McDonald, P.G., Fonseca, C.R., Overton, J.M., and Westoby, M. 2003. Leaf-size divergence along rainfall and soil-nutrient gradients: is the method of size reduction common among clades? Functional Ecology, 17(1):50-57. https://doi.org/10.1046/j.1365-2435.2003.00698.x

McKee, M.L., Royer, D.L., and Poulos, H.M. 2019. Experimental evidence for species-dependent responses in leaf shape to temperature: Implications for paleoclimate inference. PloS one, 14(6). https://doi.org/10.1371/journal.pone.0218884

Meier, I.C. and Leuschner, C. 2008. Leaf size and area index in Fagus sylvatica forests: competing effects of precipitation, temperature and nitrogen availability. Ecosystems, 11(5):655-669. https://doi.org/10.1007/s10021-008-9135-2

Miller, K.G., Mountain, G.S., Browning, J.V., Kominz, M., Sugarman, P.J., Christie-Blick, N., Katz, M.E., and Wright, J.D. 1998. Cenozoic global sea level, sequences, and the New Jersey transect: results from coastal plain and continental slope drilling. Reviews of Geophysics, 36(4):569-601. https://doi.org/10.1029/98rg01624

Moraweck, K., Uhl, D., and Kunzmann, L. 2015. Estimation of late Eocene (BartonianPriabonian) terrestrial palaeoclimate: Contributions from megafloral assemblages from central Germany. Palaeogeography, Palaeoclimatology, Palaeoecology, 433:247-258.

Moraweck, K., Grein, M., Konrad, W., Kovar-Eder, J., Kvaček, J., Neinhuis, C., Roth-Nebelsick, A., Traiser, C., and Kunzmann, L. 2019. Leaf traits of long-ranging Paleogene species and their relationship with depositional facies, climate and atmospheric $\mathrm{CO}_{2}$ level.

Palaeontographica Abteilung B, 298:93-172. https://doi.org/10.1127/palb/2019/0062

Mosbrugger, V., Utescher, T., and Dilcher, D. 2005. Cenozoic continental climatic evolution of Central Europe. Proceedings of the National Academy of Sciences, 102(42):14964-14969. https://doi.org/10.1073/pnas.0505267102

Nicotra, A.B., Leigh, A., Boyce, C.K., Jones, C.S., Niklas, K.J., Royer, D.L., and Tsukaya, H. 2011. The evolution and functional significance of leaf shape in the angiosperms. Functional Plant Biology, 38(7):535-552. https://doi.org/10.1071/FP11057

Okajima, Y., Taneda, H., Noguchi, K., and Terashima, I. 2012. Optimum leaf size predicted by a novel leaf energy balance model incorporating dependencies of photosynthesis on light and temperature. Ecological Research, 27:333-346. https://doi.org/10.1007/s11284-011-0905-5

Pälike, H., Norris, R.D., Herrle, J.O., Wilson, P.A., Coxall, H.K., Lear, C.H., Shackleton, N.J., Tripati, A.K., and Wade, B.S. 2006. The heartbeat of the Oligocene climate system. Science, 314(5807):1894-1898. https://doi.org/10.1126/science.1133822

Parkhurst, D.F. and Loucks, O. 1972. Optimal leaf size in relation to environment. Journal of Ecology, 60(2):505-537. https://doi.org/10.2307/2258359

Peppe, D.J., Royer, D.L., Cariglino, B., Oliver, S.Y., Newman, S., Leight, E., Enikolopov, G., Fernandez-Burgos, M., Herrera, F., Adams, J.M., Correa, E., Currano, E.D., Erickson, J.M., Hinojosa, L.F., Hoganson, J.W., Iglesias, A., Jaramillo, C.A., Johnson, K.R., Jordan, G.J., Kraft, N.J.B., Lovelock, E.C., Lusk, C.H., Niinemets, Ü., Peñuelas, J., Rapson, G., Wing, S.L., and Wright, I.J. 2011. Sensitivity of leaf size and shape to climate: global patterns and paleoclimatic applications. New Phytologist, 190(3):724-739. https://doi.org/10.1111/j.1469-8137.2010.03615.x

Poorter, H., Niinemets, Ü., Poorter, L., Wright, I.J., and Villar, R. 2009. Causes and consequences of variation in leaf mass per area (LMA): a meta?analysis. New Phytologist, 182(3), 565-588.

Pound, M.J. and Salzmann, U. 2017. Heterogeneity in global vegetation and terrestrial climate change during the late Eocene to early Oligocene transition. Scientific Reports, 7. https://doi.org/10.1038/srep43386

Reichgelt, T., Lee, W.G., Lusk, C.H., and Kennedy, E.M. 2017. Changes in leaf physiognomy of New Zealand woody assemblages in response to Neogene environmental cooling. Journal of Biogeography, 44(5):1160-1171. https://doi.org/10.1111/jbi.12980

Richardson, S.J., Allen, R.B., Buxton, R.P., Easdale, T.A., Hurst, J.M., Morse, C.W., Smissen, R.D., and Peltzer, D.A. 2013. Intraspecific relationships among wood density, leaf structural traits and environment in four co-occurring species of Nothofagus in New Zealand. PloS one, 8(3):e58878-e58878. https://doi.org/10.1371/journal.pone.0058878

Rojík, P. 2004. New stratigraphic subdivision of the Tertiary in the Sokolov Basin in Northwestern Bohemia. Journal of the Czech Geological Society, 49:173-186. 
Roth-Nebelsick, A., Grein, M., Traiser, C., Moraweck, K., Kunzmann, L., Kovar-Eder, J., Kvaček, J., Stiller, S., and Neinhuis, C. 2017. Functional leaf traits and leaf economics in the Paleogene - a case study for Central Europe. Palaeogeography, Palaeoclimatology, Palaeoecology, 472:1-14. https://doi.org/10.1016/j.palaeo.2017.02.008

Royer, D.L., Sack. L., Wilf, P., Lusk, C.H., Jordan, G.J., Niinemets, Ü., Wright, I.J., Westoby, M., Cariglino, B., Coley, P.D., Cutter, A.D., Johnson, K.R., Labandeira, C.C., Moles, A.T., Palmer, M.B., and Valladares, F. 2007. Fossil leaf economics quantified: calibration, Eocene case study, and implications. Paleobiology, 33:574-589. https://doi.org/10.1666/07001.1

Royer, D.L., McElwain, J.C., Adams, J.M., and Wilf, P. 2008. Sensitivity of leaf size and shape to climate within Acer rubrum and Quercus kelloggii. New Phytologist, 179(3):808-817. https://doi.org/10.1111/j.1469-8137.2008.02496.x

Royer, D.L., Meyerson, L.A., Robertson, K.M., and Adams, J.M. 2009. Phenotypic plasticity of leaf shape along a temperature gradient in Acer rubrum. PloS one, 4(10):e7653. https://doi.org/10.1371/journal.pone.0007653

Rupp, C. and Ćorić, S. 2012a. Zur Ebelsberg-Formation. Jahrbuch der Geologischen Bundesanstalt, 152:67-100.

Rupp, C. and Ćorić, S. 2012b. Zur Eferding-Formation. Jahrbuch der Geologischen Bundesanstalt, 155:33-95.

Schneider, W. 2004. Eine blätterführende Taphocoenose im 2. Miozänen Flöz von Nochten (Lausitz): Taxonomie, Taphonomie und Phytostratigraphie. Palaeontographica Abt. B, 268(13):1-74.

Scoffoni, C., Kunkle, J., Pasquet?Kok, J., Vuong, C., Patel, A.J., Montgomery, R.A., Givnish, T.J., and Sack, L. 2015. Light?induced plasticity in leaf hydraulics, venation, anatomy, and gas exchange in ecologically diverse Hawaiian lobeliads. New Phytologist, 207(1):43-58.

Sokal, R. and Rohlf, F. 2012. Biometry. WH Freeman and Company, New York.

Spicer, R.A., Valdes, P.J., Spicer, T.E.V., Craggs, H.J., Srivastava, G., Mehrotra, R.C., and Yang, J. 2009. New developments in CLAMP: calibration using global gridded meteorological data. Palaeogeography, Palaeoclimatology, Palaeoecology, 283(1-2):91-98. https://doi.org/10.1016/j.palaeo.2009.09.009

Spriggs, E.L., Schmerler, S.B., Edwards, E.J., and Donoghue, M.J. 2018. Leaf form evolution in Viburnum parallels variation within individual plants. The American Naturalist, 191(2):235249. https://doi.org/10.1086/695337

Standke, G. 2008. Paläogeographie des älteren Tertiärs (Paleozän bis Untermiozän) im mitteldeutschen Raum. Zeitschrift der Deutschen Gesellschaft für Geowissenschaften, 159:81-103

Standke, G., Escher, D., Fischer, J., and Rascher, J. 2010. Das Tertiär Nordwestsachsens - ein geologischer Überblick. Sächsisches Landesamt für Umwelt, Landwirtschaft und Geologie, Dresden.

Steart, D.C., Boon, P.J., Greenwood, D.R., and Diamond, T.N. 2002. Transport of leaf litter in upland streams of Eucalyptus and Nothofagus forests in south-eastern Australia. Archiv für Hydrobiologie, 156:43-61. https://doi.org/10.1127/0003-9136/2002/0156-0043

Su, T., Xing, Y.-W., Liu, Y.-S., Jacques, F.M.B., Chen, W.-Y., Huang, Y.-J., and Zhou, Z.-K. 2010. Leaf margin analysis: a new equation from humid to mesic forests in China. Palaios, 25(4):234-238. https://doi.org/10.2110/palo.2009.p09-129r

Tamás, J. and Hably. L. 2009. Unidirectional shift in leaf morphology of coexisting species-a possible indicator of palaeoclimatic differences. Palaeogeography, Palaeoclimatology, Palaeoecology, 271(3):185-195. https://doi.org/10.1016/j.palaeo.2008.10.007

Tanrattana, M., Bardin, J., Boura, A., Saulnier, G., and Franceschi, D.D. 2020. Variability of Cinnamomum (Lauraceae) leaf architecture in relation to climatic and historical constraints: implications for paleoclimatic studies. International Journal of Plant Sciences, 181(4):419431. https://doi.org/10.1086/706855

Teodoridis, V. and Kvaček, Z. 2015. Palaeoenvironmental evaluation of Cainozoic plant assemblages from the Bohemian Massif (Czech Republic) and adjacent Germany. Bulletin of Geosciences, 90(3):695-720.

Toumoulin, A., Kunzmann, L., Moraweck, K., and Sack, L. 2020. Reconstructing leaf area from fragments: testing three methods using a fossil Paleogene species. American Journal of Botany, 107(12):1786-1797. https://doi.org/10.1002/ajb2.1574

Tozer, W.C., Rice, B., and Westoby, M. 2015. Evolutionary divergence of leaf width and its correlates. American Journal of Botany, 102(3):367-378. https://doi.org/10.3732/ajb.1400379 
Traiser, C., Klotz, S., Uhl, D., and Mosbrugger, V. 2005. Environmental signals from leaves - a physiognomic analysis of European vegetation. New Phytologist, 166(2):465-484. https://doi.org/10.1111/j.1469-8137.2005.01316.x

Traiser, C., Roth-Nebelsick, A., Grein, M., Kovar-Eder, J., Kunzmann, L., Moraweck, K., Lange, J., Kvaček, J., Neinhuis, C., and Folie, A. 2018. MORPHYLL: a database of fossil leaves and their morphological traits. Palaeontologia Electronica, 21(1):1-17. https://doi.org/10.26879/773

Tramoy, R., Salpin, M., Schnyder, J., Person, A., Sebilo, M., Yans, J., Vaury, V., Fozzani, J., and Bauer, H. 2016. Stepwise palaeoclimate change across the Eocene-Oligocene transition recorded in continental NW Europe by mineralogical assemblages and $\delta^{15} \mathrm{~N}_{\text {org }}$ (Rennes Basin, France). Terra Nova, 28(3):212-220. https://doi.org/10.1111/ter.12212

Tranquillini, W. 1982. Frost-drought and its ecological significance, p. 379-400. In Lange, O.L., Nobel, P.S., Osmond, C.B., and Ziegler, H. (eds.), Physiological Plant Ecology II. Springer, Berlin, Heidelberg, New York.

Utescher, T., Bondarenko, O.V., and Mosbrugger, V. 2015. The Cenozoic cooling-continental signals from the Atlantic and Pacific side of Eurasia. Earth and Planetary Science Letters, 415:121-133. https://doi.org/10.1016/j.epsl.2015.01.019

Valladares, F., Gianoli, E., and Gómez, J.M. 2007. Ecological limits to plant phenotypic plasticity. New Phytologist, 176(4):749-763. https://doi.org/10.1111/j.1469-8137.2007.02275.x

Valladares, F., Wright, S.J., Lasso, E., Kitajima, K., and Pearcy, R.W. 2000. Plastic phenotypic response to light of 16 congeneric shrubs from a Panamanian rainforest. Ecology, 81(7):1925-1936. https://doi.org/10.1890/0012-9658(2000)081[1925:pprtlo]2.0.co;2

Velitzelos, D., Bouchal, J. M., and Denk, T. 2014. Review of the Cenozoic floras and vegetation of Greece. Review of Palaeobotany and Palynology, 204:56-117. https://doi.org/10.1016/ j.revpalbo.2014.02.006

Walliser, E., Lohmann, G., Niezgodzki, I., Tütken, T., and Schöne, B. 2016. Response of Central European SST to atmospheric $\mathrm{pCO}_{2}$ forcing during the Oligocene-a combined proxy data and numerical climate model approach. Palaeogeography, Palaeoclimatology, Palaeoecology, 459:552-569. https://doi.org/10.1016/j.palaeo.2016.07.033

Walther, H. 1985. Das Vorkommen der Gattung Platanus L. im Tertiär des Weisselster-Beckens (Bezirk Leipzig, DDR). Hallesches Jahrbuch für Geowissenschaften, 10:9-19.

Walther, H. 1999. Die Tertiärflora von Kleinsaubernitz bei Bautzen. Palaeontographica, Abt. B Palaeophytologica, 249:63-174.

Wilf, P. 1997. When are leaves good thermometers? A new case for Leaf Margin Analysis. Paleobiology, 23:373-390. https://doi.org/10.1017/S0094837300019746

Wilf, P., Wing, S.L., Greenwood, D.R., and Greenwood, C.L. 1998. Using fossil leaves as paleoprecipitation indicators: an Eocene example. Geology, 26:203-206. https://doi.org/10.1130/0091-7613(1998)026<0203:UFLAPI>2.3.CO;2

Wolfe, J.A. 1993. A method of obtaining climatic parameters from leaf assemblages. U.S. Geological Survey Bulletin, 2040:1-71.

Wolfe, J.A. 1995. Paleoclimate estimates from Tertiary leaf assemblages. Annual Review of Earth and Planetary Sciences, 23:119-142. https://doi.org/10.1146/annurev.ea.23.050195.001003

Wright, I.J., Reich, P.B., Westoby, M., Ackerly, D.D., Baruch, Z., Bongers, F., Cavender-Bares, J., Chapin, T., Cornelissen, J.H.C., Diemer, M., Flexas, J., Garnier, E., Groom, P.K., Gulias, J., Hikosaka, K., Lamont, B.B., Lee, W., Lusk, C., Midgley, J.J., Navas, M.-L., Niinments, Ü., Oleksyn, J., Osada, N., Poorter, H., Poot, P., Prior, L., Pyankov, V.I., Roumet, C., Thomas, S.C., Tjoelker, M.G., Veneklaas, E.J., and Villar, R. 2004. The worldwide leaf economics spectrum. Nature, 428:821-827. https://doi.org/10.1038/nature02403

Wright, I.J., Dong, N., Maire, V., Prentice, I.C., Westoby, M., Díaz, S., Gallagher, R.V., Jacobs, B.F., Kooyman, R., and Law, E.A. 2017. Global climatic drivers of leaf size. Science, 357(6354):917-921. https://doi.org/10.1126/science.aal4760

$\mathrm{Xu}, \mathrm{Z}$., Hu, T., and Zhang, Y. 2012. Effects of experimental warming on phenology, growth and gas exchange of treeline birch (Betula utilis) saplings, Eastern Tibetan Plateau, China. European Journal of Forest Research, 131(3):811-819. https://doi.org/10.1007/s10342-011-0554-9 
ROTH-NEBELSICK ET AL.: TAXON-SPECIFIC VARIABILITY

Yang J., Spicer, R.A., Spicer, T.E.V., Arens, N.C., Jacques, F.M.B., Su, T., Kennedy, E.M., Herman, A.B., Steart, D.C., Srivastava, G., Mehrotra, R.C., Valdes, P.J., Mehrotra, N.C., Zhou, Z., and Lai, J. 2015. Leaf form-climate relationships on the global stage: an ensemble of characters. Global Ecology and Biogeography, 24(10):1113-1125. https://doi.org/10.1111/geb.12334

Zachos, J.C., Dickens, G.R., and Zeebe, R.E. 2008. An early Cenozoic perspective on greenhouse warming and carbon-cycle dynamics. Nature, 451:279-283.

https://doi.org/10.1038/nature06588 


\section{APPENDIX 1.}

All data used for the present study. Data for Appendix 1 and 2 is in zipped file for download at https://palaeo-electronica.org/content/2021/3285-taxon-specific-variability.

\section{APPENDIX 2.}

CLAMP results for mean annual temperature (MAT) and growing season precipitation (GSP), for the considered sites (site numbers see Table 1). Data for Appendix 1 and 2 is in zipped file for download at https://palaeo-electronica.org/content/2021/3285-taxon-specific-variability. 